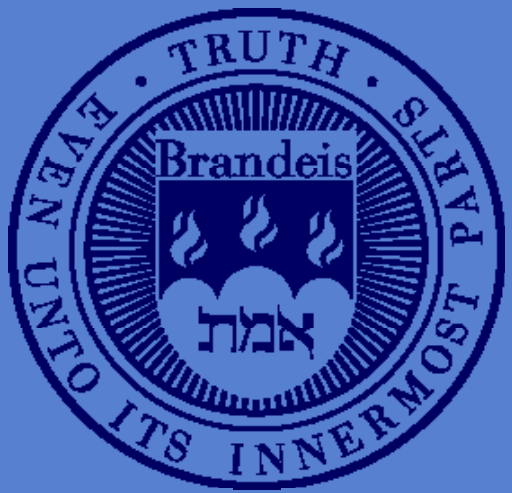

Death, Bereavement, and Creativity

Kathryn Graddy, Economics Department, Brandeis University 


\title{
Death, Bereavement, and Creativity
}

\author{
Kathryn Graddy ${ }^{2}$
}

July 23,2015

${ }^{1}$ Brandeis University, kgraddy@brandeis.edu,tel:7817368616

${ }^{2}$ Thanks to Carl Lieberman for excellent research assistance and for participants in the Faculty Lunch at Brandeis and the Art Markets Workshop in Brussels for comments. 


\begin{abstract}
Does creativity, on average, increase or decrease during bereavement? Dates of death of relatives and close friends of 33 French artists and 15 American artists were gathered from electronic sources and biographies, and information on over 15,000 paintings was collected from Blouin's Art Sales Index and the Metropolitan Museum of Art's online collection, including over 12,000 observations on price. To preview the results, an event study indicates that prices of paintings decrease by over one-third on average in the two years following the death of a friend or relative. Furthermore, paintings that were created during this bereavement period are less likely to be included in the the Met's collection.
\end{abstract}




\section{Introduction}

The death of a friend or relative is universally recognized as a painful experience. Whether the psychological pain resulting from the death increases or decreases creativity is not known. On the one hand, incidental observation of the history of art suggests that bereavement is correlated to the production of great art. For example, in 1901, Pablo Picasso's good friend, Carlos Casagemas, committed suicide. Many art historians believe that this event launched Picasso into his Blue Period of painting, in which Picasso painted somber monochromastic works. Picasso's Blue Period has in the past achieved record prices at auction. ${ }^{1}$ On the other hand, questions remain as to the impact of bereavement on an artist's state of mind. In the field of psychology, state of mind has long been associated with creativity through the idea of being completely absorbed in an activity, named by Michael Csikszentmihalyi as a "flow state" (May (1959), Getzels and Csikszentmihalyi (1976), and Isen et al. (1987)). Bereavement can interupt flow and alter mood. The empirical question of whether the death of a relative or close friend on average increases or decreases creativity in the years immediately following the death is addressed by this research.

Dates of death for friends and relatives of the French artists used in this study were gathered from Oxford Art Online, reading both Grove Art Online

\footnotetext{
${ }^{1}$ In 2000, Woman with Crossed Arms broke a previous record for Picasso paintings by selling for 38 million pounds. This price pales, however, next to the recent sale of the Women of Algiers (Version O) for $\$ 179$ million at Christie's during May of 2015.
} 
and the Benezit Dictionary of Artists. For the American artists used in this study, dates of death were gathered primarily from biographies. Information on over 15,000 paintings was gathered from Blouin's Art Sales Index and the Metropolitan Museum of Art's online collection, including over 12,000 observations on price. The basic economic premises of this research are that price reflects a painting's importance within an artist's oeuvre, and that an artist's most important paintings are likely to be included in Met's collection.

While art is a convenient medium in which to study the effect of a close friend's or relative's death on creativity, the results should extend to other creative endeavors, such as scientific creativity. The attraction of studying art in order to measure the effect of bereavement is that it is known when a painting is produced, and the importance of a creation can be measured by its price and inclusion in a museum's collection. The data exist in art that enable researchers to measure this psychological effect, whereas in other areas, the effect would be more difficult to measure.

This paper proceeds as follows. In section II, the psychology literature on creativity is briefly reviewed. In section III the paper details the data collection procedures and regression methodology. In section IV, the price regression results are presented, and robustness of the price regressions is discussed in section V. Section VI analyses inclusion in the Metropolitan Museum of Art's collection, and section VII concludes the analysis. 


\section{Creativity and State of Mind}

The concept of a "flow state" that people enter when being very creative has gained acceptance by psychologists. As described by Keith Sawyer (Sawyer (2012), p. 78), Rollo May was one of the first researchers to describe the experience of being in a creative state as experiencing intensity of awareness, heightened consciousness, and obvliousness to the environment and to the passage of time (May (1959)). Czikscentmihalyi continued this strand of research, and coined the term "flow state" (Getzels and Csikszentmihalyi (1976)). During flow, people are at their most creative. Csikszentmihalyi did further studies that showed that in all professions people feel at their peak when they are most creative, and therefore through flow individuals can achieve happiness (Csikszentmihalyi (1990)).

Distraction is an enemy of flow and creativity. At best, it could take hours to regain the peace of mind to resume a creative endeavour. At worst, "More serious health, family, or financial problems could occupy the mind of a person so insistently that he or she is no longer able to devote enough attention to work. Then a long period of drought may follow, a writer's block, a burnout, which may even end a creative career" (Csikszentmihalyi (1997), p.120). Through interupting flow, death and bereavement can reduce creativity.

Psychologists then surmised that if the flow experience is correlated with enhanced creativity, then mood is related to creativity. Using experiements, 
researchers showed that mood is strongly related to problem solving (Isen et al. (1987)), (Subramaniam et al. (2009)). Death and bereavement interupt flow and can result in sadness and depression.

To date, there have been few if any empirical studies that have related mood to creativity, though economists and others have used empirical methods to document productivity over the life cycle. Galenson and Weinberg (2000) and Galenson and Weinberg (2001) have extensively studied the productivity of artists over the lifecycle, and Simonton (1990) presents a general study of other professions. The idea for this study came from a case study of three musicians by Karol Jan Borowiecki (2013) as presented at the Genius for Sale! conference in Oxford on May 8th, 2014.

Academic studies have related death to creativity through different venues. It is well documented that individuals deemed "geniuses" were more likely to have suffered a parental loss as a child or adolescent. See for example Eisenstadt (1978) and Simonton (1984). Indeed, of the 15 American artists included in this study, four artists (Mark Rothko, Arshile Gorky, Franz Kline, and Philip Guston) all experienced the death of a parent as a child. In a very interesting and original study, Azoulay et al. (2010) looked at unexpected deaths of "superstar" researchers and subsequent productivity of coauthors. They find a lasting decline of between $5 \%$ and $8 \%$ in quality adjusted publication output of the coauthors. They explain this lasting decline by the loss of an irreplaceable source of ideas.

The research in this paper is very different in spirit. All individuals 
experience loss through death of a close relative or friend at some point in their lives, geniuses and superstars included. This paper seeks to measure the effect of this loss on creative output. The hypothesis is that alteration in mood and inability to focus during bereavement may affect creative output.

\section{Data and Methodology}

The question of the effect of death on creativity is addressed with prices on over 10,000 paintings produced by 33 French impressionist artists and over 2,000 paintings by 15 modern American artists born between 1900 and 1920. The auction data were gathered online from Blouin's Art Sales Index. ${ }^{2}$ The sale dates range from 1972 to 2014. In addition, information on 412 paintings in the Metropolitan Museum of Art's collection was downloaded from the Met's website. ${ }^{3}$

The artists chosen were those first analyzed in Galenson and Weinberg (2000) and Galenson and Weinberg (2001). The French impressionists were originally chosen by Galenson and Weinberg according to importance to art history and connection to France. Galenson and Weinberg wanted to choose two different cohorts of American artists, with the first cohort, which is used in this paper, dominated by abstract expressionists. ${ }^{4}$ The French artists used

\footnotetext{
${ }^{2}$ The url for Blouin's Art Sales Index is http://artsalesindex.artinfo.com/asi/search.action and the data were downloaded during June of 2014.

${ }^{3}$ The url for the Met's collection is http://www.metmuseum.org/collection/thecollection-online and the website was accessed on June 15, 2015.

${ }^{4}$ I had originally planned to gather death data on both cohorts of American artists. But, given the difficulty, relative to the French cohort, of gathering data on the first
} 
in this study are listed in Table I, and the American artists used in this study are listed in Table II, along with the number of deaths of friends and relatives that were found for each artist. All French impressionists and American abstract expressionists that were studied by Galenson and Weinberg (2001) and Galenson and Weinberg (2000) are included in this table, even those artists on whom we were unable to find death data for their friends or relatives. The death dates for the French artists were gathered from Oxford Art Online, reading both Grove Art Online and the Benezit Dictionary of Artists, and the death dates of American artists were gathered from websites and biographies. Appendix A includes the references used for American artists, and Appendix B includes the references used for French artists.

When gathering the data, Oxford Art Online was not useful for any of the American artists, and it was necessary to use a mixture of websites and biographies from the library to collect the data. Probably because of genealogy records, deaths of parents were much more assiduously recorded for the American artists, who lived more recently, than the French artists. A mythology has also likely grown around the lives of both sets of artists, perhaps more so around the French impressionists, that may affect the reporting of certain deaths.

Summary statistics for this dataset, broken up by French artists and American artists, are presented in Table III. The prices presented are in American cohort, and since most of the second cohort of artists are still alive, I stopped after the first American cohort. 
Table I: French Artists

\begin{tabular}{lc}
\hline \hline French Artists & Deaths \\
\hline Jean Arp (b. 1886, d. 1966) & 1 \\
Roger Bissiere (b. 1884, d. 1964) & 4 \\
Pierre Bonnard (b. 1867, d. 1947) & 2 \\
Georges Braque (b. 1882, d. 1963) & 1 \\
Paul Cezanne (b. 1839, d. 1906) & 3 \\
Marc Chagall (b. 1887, d. 1985) & 2 \\
Maurice de Vlaminck (b. 1876, d. 1958) & 0 \\
Henri de Toulouse-Lautrec (b. 1864, d. 1901) & 0 \\
Edgar Degas (b. 1834, d. 1917) & 2 \\
Robert Delaunay (b. 1885, d. 1941) & 0 \\
Andre Derain (b. 1880, d. 1954) & 0 \\
Marcel Duchamp (b. 1887, d. 1968) & 0 \\
Raoul Dufy (b. 1877, d. 1953) & 0 \\
Paul Gauguin (b. 1848, d. 1903) & 3 \\
Juan Gris (b. 1887, d. 1927) & 0 \\
Henri Julien Felix Rousseau (b. 1844, d. 1910) & 3 \\
Fernand Leger (b. 1881, d. 1955) & 2 \\
Edouard Manet (b. 1832, d. 1883) & 2 \\
Andre Masson (b. 1896, d. 1987) & 1 \\
Henri Matisse (b. 1869, d. 1954) & 1 \\
Joan Miro (b. 1893, d. 1983) & 2 \\
Claude Monet (b. 1840, d. 1926) & 5 \\
Francis Picabia (b. 1879, d. 1953) & 0 \\
Pablo Picasso (b. 1881, d. 1973) & 1 \\
Camille Pissarro (b. 1830, d. 1903) & 5 \\
Odilon Redon (b. 1840, d. 1916) & 0 \\
Pierre-Auguste Renoir (b. 1841, d. 1919) & 1 \\
Georges Rouault (b. 1871, d. 1958) & 2 \\
Georges Seurat (b. 1859, d. 1891) & 0 \\
Chaim Soutine (b. 1893, d. 1943) & 1 \\
Yves Tanguy (b. 1900, d. 1955) & \\
Vincent van Gogh (b. 1853, d. 1890) & \\
Edouard Vuillard (b. 1868, d. 1940) & \\
\hline \hline &
\end{tabular}


Table II: American Artists

\begin{tabular}{lc}
\hline \hline American Artists & Deaths \\
\hline Willem de Kooning (b. 1904, d. 1997) & 2 \\
Arshile Gorky (b. 1904, d. 1948) & 3 \\
Adolph Gottlieb (b. 1903, d. 1974) & 3 \\
Philip Guston (b. 1913, d. 1980) & 3 \\
Franz Kline (b. 1910, d. 1962) & 1 \\
Morris Louis (b. 1912, d. 1962) & 0 \\
Agnes Martin (b. 1912, d. 2004) & 1 \\
Robert Motherwell (b. 1915, d. 1991) & 2 \\
Alice Neel (b. 1900, d. 1984) & 3 \\
Barnett Newman (b. 1905, d. 1970) & 4 \\
Jackson Pollock (b. 1912, d. 1956) & 3 \\
Fairfield Porter (b. 1907, d. 1975) & 2 \\
Ad Reinhardt (b. 1913, d. 1967) & 0 \\
Mark Rothko (b. 1903, d. 1970) & 1 \\
Clyfford Still (b. 1904, d. 1980) & 2 \\
\hline \hline
\end{tabular}

2010 dollars and are deflated by the CPI. The French artists were born earlier on average than the American artists. The price and age variables are similar to one another, but there are over twice as many paintings per French impressionist as there are paintings for each American artist included in the dataset.

An event study is used for the regression analysis. For the event study, each sale is an observation. As shown in equation 1 below, the dependent variable is the natural log of the price of painting $i$ that was sold at time j. A zero-one variable is created that indicates whether the painting was produced the first or second year prior to the death of the friend or relative, Prior $_{i j}$. Unless the death was foreseeable, this variable should not have an 
Table III: Summary Statistics

\begin{tabular}{lccc}
\hline \hline & French & American & All \\
\hline Year of birth & 1872 & 1908 & 1878 \\
& $(19)$ & $(5)$ & $(22)$ \\
Painting date & 1924 & 1962 & 1931 \\
& $(28)$ & $(12)$ & $(30)$ \\
Age of artist & 53 & 54 & 53 \\
& $(18)$ & $(12)$ & $(17)$ \\
Year of sale & 2002 & 2001 & 2002 \\
& $(9)$ & $(10)$ & $(9)$ \\
Price & 1463567 & 1517807 & 1472652 \\
& $(4376458)$ & $(5586213)$ & $(4601108)$ \\
\hline Observations & 11752 & 2292 & 14044 \\
Number of artists & 33 & 15 & 48 \\
Paintings per artist & 545 & 223 & 492 \\
\hline \hline Note:Standard deviations are in parentheses. Prices in 2010 dollars are deflated with the CPI. \\
Source: Blouin Art Sales Index; see text.
\end{tabular}


effect. Another zero-one variable indicating whether the friend or relative died during the year the work was painted, Current $_{i j}$, is also created. It is not possible to establish when in a year the painting was created or whether the death occurred before or after a particular work was created. Two more variables are created, $A f t e r(1)_{i j}$ and $A f t e r(2)_{i j}$, indicating whether the work was produced in the 1st or 2nd year following the death of a friend or relative. Finally, a variable, After $(3,4)_{i j}$, was created indicating whether the work was painted in the 3rd or 4th year after the death of the friend or relative. The coefficients on these variables are $\alpha_{1}$ through $\alpha_{5}$, as indicated in equation 1 below.

Five different cohorts, interacted with $a g e, a g e^{2}, a g e^{3}$, and $a g e^{4}$, are used for controls. Cohorts one through four coincide with the four cohorts for French painters used by Galenson and Weinburg (2001). That is, cohort 1 consists of French painters in the dataset born between 1820 and 1839, cohort 2 consists of those French painters born between 1840 and 1859, cohort 3 consists of those French painters born between 1860 and 1879, and cohort 4 consists of those French painters born between 1880 and 1900 . Cohort 5 consists of American painters and coincides with Galenson and Weinberg's (2000) first cohort of American painters. The cohorts have coefficients $\beta_{1}$ through $\beta_{5}$. Artist fixed effects with coefficients $\psi_{k}$, year fixed effects with coefficients $\theta_{y}$, and in the full specification, fixed effects for painting date, with coefficients $\omega_{y}$, and an error term, $\epsilon_{i j}$ are also included in the regressions. These controls are similar to those used in Galenson and Weinberg (2000) 
and Galenson and Weinberg (2001). ${ }^{5}$

$$
\begin{aligned}
& \ln \left(\text { Price }_{i j}=\alpha_{1} \text { Prior }_{i}+\alpha_{2} \text { Current }_{i}+\alpha_{3} \text { After }(1)_{i}+\alpha_{4} \text { After }(2)_{i}+\alpha_{5} \text { After }(3,4)_{i}\right. \\
& +\sum_{c=1}^{4}\left[\beta_{1}^{c} A_{g e_{i}}+\beta_{2}^{c} A g e_{i}^{2}+\beta_{3}^{c} A g e_{i}^{3}+\beta_{4}^{c} A g e_{i}^{4}\right] I\left(\text { cohort }_{i}=C\right) \\
& +\sum_{k=1}^{48} \psi_{k} I(i=k)+\sum_{y=1972}^{2014} \theta_{y} I\left(\text { Saleyear }_{j}=y\right) \\
& +\sum_{y=1840}^{y=1972} \omega_{y} I\left(\text { Paintingdate }_{i}\right)+\epsilon_{i j}
\end{aligned}
$$

\section{Results}

Of the 14,044 observations, a sale price was observed for 12,705 observations. The auction results included 164 paintings by American artists and 1,175 paintings by French artists that went unsold at auction because they did not meet the reserve price. ${ }^{6}$ The results from estimating regression equation 1 are presented in Table IV.

Columns 1 and 3 present the results of unweighted regressions, and columns 2 and 4 present weighted regressions. Columns 3 and 4 include painting date fixed effects and columns 1 and 2 do not. To control for differ-

\footnotetext{
${ }^{5}$ Area of work was used in these papers, but was not originally collected for this dataset. Section V.A. describes a specification that was used to test for robustness with respect to area.

${ }^{6}$ Note that the Blouin Art Sales Index does not include all unsold items from all auctions.
} 
ences in the variability of different artists' sale prices, each artist's paintings are weighted by the mean square error for that artist. Unweighted regressions implicitly weight artists with more sales more heavily than artists with fewer sales. As the mean squared error takes into account both the number of works for sale and the variability in sale prices, the inverse of the mean squared error appears to be the correct weight. The results are similar when each work is weighted by the inverse of the number of paintings by an artist, so that each artist receives equal weight. Robust errors are calculated with the observations clustered by artist.

Results are consistent in both the weighted and unweighted regressions. The weighted regressions indicate that the value of a painting decreases by about $50 \%$ for paintings created in the year following the death of the artists' friend or relative. There is no significant effect in other years. These results are consistent with the psychology literature relating to mood and creativity, but not consistent with the popular idea that suffering necessarily increases artistic creativity.

In order to check that the results are consistent with the results of Galenson and Weinberg (2001), the peak age of earnings for each French Impressionist are estimated using regression equation 1, weighted by the inverse of the mean squared error and including painting date fixed effects. These estimated peak ages are presented in Table V. The results are similar, with peak age of artist declining by year cohort. ${ }^{7}$ This research supports

\footnotetext{
${ }^{7}$ Galenson and Weinberg explain this decline by the hypothesis that artists in the
} 
Table IV: Determinants of Sale Price

\begin{tabular}{|c|c|c|c|c|}
\hline & (1) & $(2)$ & 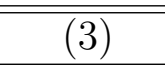 & (4) \\
\hline Painted in 1st or 2 nd year prior to death & $\begin{array}{l}-0.0299 \\
(0.143)\end{array}$ & $\begin{array}{c}0.223 \\
(0.160)\end{array}$ & $\begin{array}{c}0.130 \\
(0.151)\end{array}$ & $\begin{array}{l}0.0980 \\
(0.148)\end{array}$ \\
\hline Painted in year of death & $\begin{array}{l}-0.127 \\
(0.119)\end{array}$ & $\begin{array}{c}-0.333 \\
(0.271)\end{array}$ & $\begin{array}{l}-0.180 \\
(0.240)\end{array}$ & $\begin{array}{l}-0.111 \\
(0.173)\end{array}$ \\
\hline Painted in 1st year after death & $\begin{array}{c}-0.409^{* * *} \\
(0.0944)\end{array}$ & $\begin{array}{c}-0.415^{*} \\
(0.199)\end{array}$ & $\begin{array}{c}-0.470^{* *} \\
(0.161)\end{array}$ & $\begin{array}{c}-0.530^{* * *} \\
(0.131)\end{array}$ \\
\hline Painted in 2 nd year after death & $\begin{array}{c}-0.247^{*} \\
(0.116)\end{array}$ & $\begin{array}{c}-0.0414 \\
(0.198)\end{array}$ & $\begin{array}{l}-0.228 \\
(0.173)\end{array}$ & $\begin{array}{l}-0.245 \\
(0.160)\end{array}$ \\
\hline Painted in 3rd or 4th year after death & $\begin{array}{l}0.0109 \\
(0.149)\end{array}$ & $\begin{array}{c}0.387 \\
(0.228)\end{array}$ & $\begin{array}{c}0.169 \\
(0.163)\end{array}$ & $\begin{array}{c}0.134 \\
(0.191)\end{array}$ \\
\hline Observations & 12705 & 12705 & 12705 & 12705 \\
\hline Artist fixed effects & Yes & Yes & Yes & Yes \\
\hline Year of sale fixed effects & Yes & Yes & Yes & Yes \\
\hline $\begin{array}{l}\text { Cohort fixed effects interacted with } \\
\text { age, age }^{2}, \text { age }^{3}, \text { age }^{4} \\
\text { Painting date fixed effects }\end{array}$ & $\begin{array}{l}\text { Yes } \\
\text { No }\end{array}$ & $\begin{array}{l}\text { Yes } \\
\text { No }\end{array}$ & $\begin{array}{l}\text { Yes } \\
\text { No }\end{array}$ & $\begin{array}{l}\text { Yes } \\
\text { Yes }\end{array}$ \\
\hline
\end{tabular}

Standard errors in parentheses

Standard errors are robust, clustered by artist

Regressions in columns (1) and (3) are unweighted

Regressions in columns (2) and (4) are weighted

by the inverse of the sum of the mean squared error for each artist

${ }^{*} p<0.05,{ }^{* *} p<0.01,{ }^{* * *} p<0.001$ 
their empirical analysis with a different dataset of sales. These sales took place from 1972 through 2014; the Galenson and Weinberg sales took place from 1980 to 1996.

\begin{tabular}{|c|c|c|c|c|}
\hline & \multicolumn{4}{|c|}{ French Artists } \\
\hline & $1820-1839$ & $1840-1859$ & 1860-1879 & $1880-1900$ \\
\hline Peak Age Estimates & 53 & 49 & 30 & 27 \\
\hline $\begin{array}{l}\text { Galenson and Weinberg } \\
\text { Peak Age Estimates* }\end{array}$ & 48 & 38 & 28 & 28 \\
\hline
\end{tabular}

Notes:*Galenson and Weinberg (2001)

\section{Robustness Checks}

This section checks for robustness in three ways. First, this section checks whether including size of painting changes the results. Secondly, this section checks whether the results differ in the dataset on French Impressionists from the results in the dataset on American Modern painters. Finally, this section checks if the results depend upon whether a parent has died or whether a sibling or friend has died.

latest cohort were "conceptualists," valuing new ideas above technique, and artists in the earlier cohort were "experimentalists," whose style developed slowly through trialand-error experimentation. Conceptualists reach their peak production age earlier than experiementalists. Ginsburgh and Weyers (2006) provide a critique of this hypothesis. 


\section{V.A. Size of Work}

The dataset on prices and deaths put together for this research did not contain information on the size of a work. As the variable of interest is death, this omission could impact the results if size of work is correlated with mood. In order to check for this possibility, the average area (height times width) of work for each French Impressionist artist at each age of the artist was collected from the dataset used in Ashenfelter and Graddy (2003) and Beggs and Graddy (1997). If an age was missing for a particular artist, the size was replaced with the average size painted at the previous age for that artist. If information on size was missing for the artist overall (the Modern American painters were not included in these datasets), the artist was dropped. Results are presented in Table VI.

Once the sample is taken into account, the inclusion of area has almost no effect: none of the coefficients in the regression models including area are statistically significantly different from any of the coefficients in the regression models not including area. However, in this change of sample, the coefficients on year of death, 1st year after death and 2nd year after death all become statistically significantly negative, strengthening the previous results.

\section{V.B. French Impressionists Compared to Modern Americans}

The increased significance of death on price in the year of death and 1st and 2nd year following death in the above regression sample raises the question as to whether death effects in the sample of French Impressionist painters differ 
Table VI: Determinants of Sale Price: Sample with Area

\begin{tabular}{lcccc}
\hline \hline & $\begin{array}{c}(1) \\
\text { lnprice }\end{array}$ & $\begin{array}{c}(2) \\
\text { lnprice }\end{array}$ & $\begin{array}{c}(3) \\
\text { lnprice }\end{array}$ & $\begin{array}{c}(4) \\
\text { lnprice }\end{array}$ \\
\hline ln Area & $0.168^{*}$ & $0.161^{* *}$ & & \\
& $(0.0723)$ & $(0.0525)$ & & \\
Painted in 1st or 2nd year prior to death & -0.134 & -0.174 & -0.167 & -0.191 \\
& $(0.134)$ & $(0.172)$ & $(0.135)$ & $(0.173)$ \\
& $-0.715^{*}$ & $-0.692^{* *}$ & $-0.732^{*}$ & $-0.705^{* *}$ \\
Painted in year of death & $(0.294)$ & $(0.189)$ & $(0.289)$ & $(0.188)$ \\
& $-0.535^{*}$ & $-0.520^{* *}$ & $-0.611^{*}$ & $-0.587^{* *}$ \\
& $(0.252)$ & $(0.163)$ & $(0.247)$ & $(0.163)$ \\
Painted in 1st year after death & $-0.456^{* *}$ & $-0.529^{* * *}$ & $-0.496^{* *}$ & $-0.560^{* * *}$ \\
& $(0.158)$ & $(0.137)$ & $(0.148)$ & $(0.130)$ \\
& & & & \\
Painted in 2nd year after death & 0.110 & 0.0188 & 0.109 & 0.0122 \\
& $(0.241)$ & $(0.220)$ & $(0.237)$ & $(0.216)$ \\
\hline Painted in 3rd or 4th year after death & 8035 & 8035 & 8035 & 8035 \\
& Yes & Yes & Yes & Yes \\
& Yes & Yes & Yes & Yes \\
Observations $_{\text {Artist fixed effects }}$ & & & & \\
Year of sale fixed effects & Yes & Yes & Yes & Yes \\
Cohort fixed effects interacted with & No & Yes & No & Yes \\
age, age ${ }^{2}$, age ${ }^{3}$, age & & & & \\
Painting date fixed effects & & & &
\end{tabular}

Standard errors in parentheses

Standard errors are robust, clustered by artist.

Regressions are weighted by the inverse of the mean squared error for each artist

${ }^{*} p<0.05,{ }^{* *} p<0.01,{ }^{* * *} p<0.001$ 
from death effects in the sample of Modern American painters. In Table VII, a set of new variables is created by interacting an indicator variable, equal to 1 if the artist is a French Impressionist and 0 if not, with painting dates relative to deaths.

The coefficients on the Modern American painters are not precisely estimated, which is not surprising given the smaller sample of only 15 Modern American painters. However, the point estimates for works created in the year after death are consistent with other results. Furthermore, the estimates of the coefficient on works painted one year after death are statistically significantly lower than the coefficients on works painted 1 or 2 years prior to the death of the artist. The coefficients on the French Impressionist artists are statistically significantly negative for works created in the 1st and 2nd year after death of a friend or relative.

\section{V.C. Parent Death Compared to a Sibling or Friend Death}

In Table 8 , yet another set of new variables is created by interacting an indicator variable, equal to 1 if a parent has died, and 0 if a sibling or friend has died, with painting dates relative to these deaths.

The results indicate there is no statistically significant difference whether the death involved a parent, or whether the death involved a sibling or friend. 
Table VII: Determinants of Sale Price

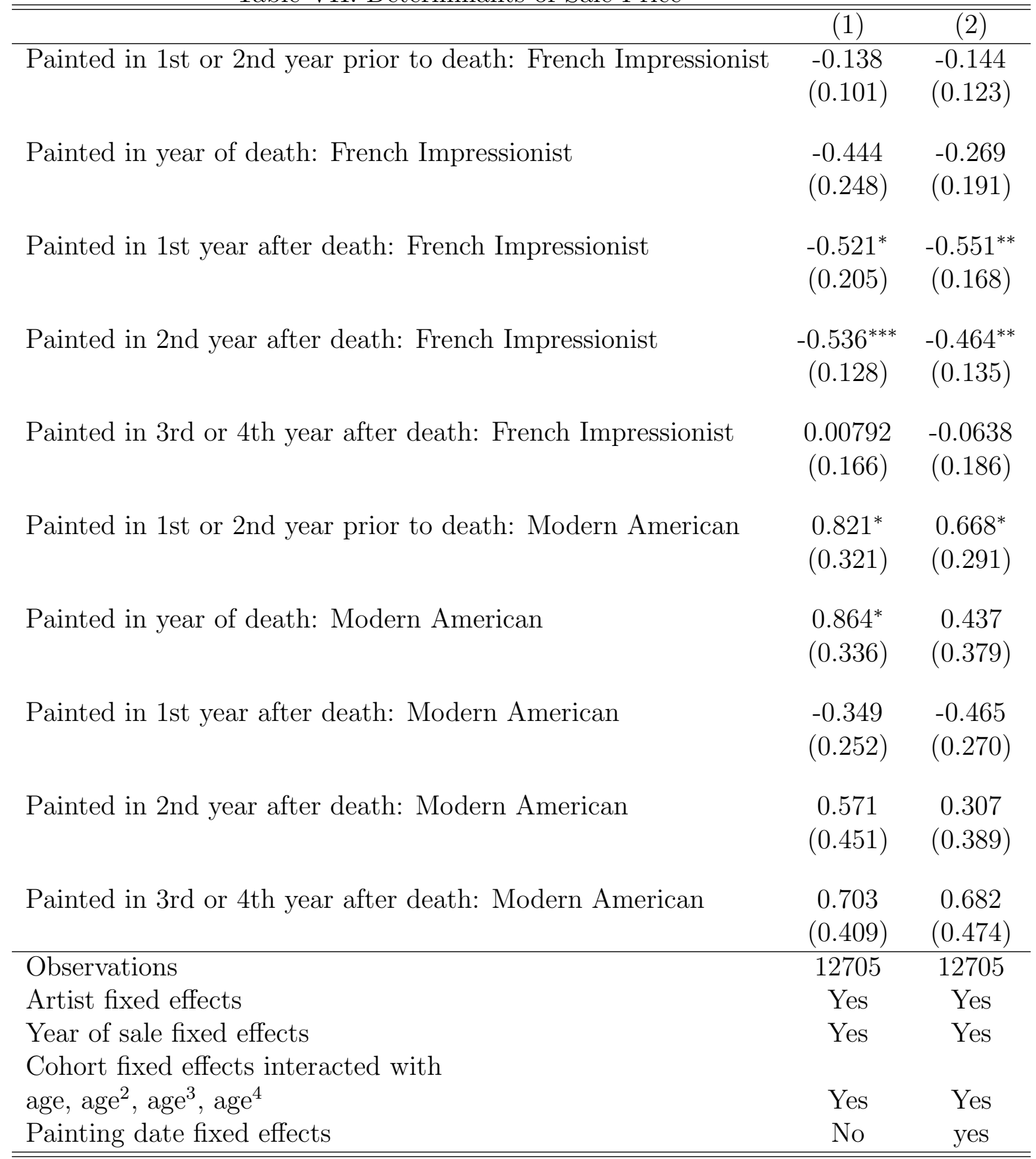

Standard errors in parentheses

Standard errors are robust, clustered by artist.

Regressions are weighted by the inverse of the mean squared error for each artist

${ }^{*} p<0.05,{ }^{* *} p<0.01,{ }^{* * *} p<0.001 \quad 18$ 
Table VIII: Determinants of Sale Price

\begin{tabular}{|c|c|c|}
\hline & (1) & $(2)$ \\
\hline Painted in 1st or 2nd year prior to death of parent & $\begin{array}{c}0.339 \\
(0.320)\end{array}$ & $\begin{array}{c}0.160 \\
(0.317)\end{array}$ \\
\hline Painted in year of death of parent & $\begin{array}{l}-0.220 \\
(0.609)\end{array}$ & $\begin{array}{c}-0.0902 \\
(0.312)\end{array}$ \\
\hline Painted in 1st year after death of parent & $\begin{array}{c}-0.679 \\
(0.381)\end{array}$ & $\begin{array}{c}-0.752^{*} \\
(0.288)\end{array}$ \\
\hline Painted in 2nd year after death of parent & $\begin{array}{l}-0.317 \\
(0.408)\end{array}$ & $\begin{array}{c}-0.554 \\
(0.397)\end{array}$ \\
\hline Painted in 3rd or 4th year after death of parent & $\begin{array}{c}0.171 \\
(0.336)\end{array}$ & $\begin{array}{c}0.107 \\
(0.332)\end{array}$ \\
\hline Painted in 1st or 2nd year prior to death of sibling or friend & $\begin{array}{c}0.0308 \\
(0.121)\end{array}$ & $\begin{array}{l}0.0635 \\
(0.127)\end{array}$ \\
\hline Painted in year of death of sibling or friend & $\begin{array}{c}-0.169 \\
(0.213)\end{array}$ & $\begin{array}{c}-0.0890 \\
(0.230)\end{array}$ \\
\hline Painted in 1st year after death of sibling or friend & $\begin{array}{c}-0.374^{*} \\
(0.164)\end{array}$ & $\begin{array}{c}-0.411^{*} \\
(0.175)\end{array}$ \\
\hline Painted in 2nd year after death of sibling or friend & $\begin{array}{c}-0.202 \\
(0.188)\end{array}$ & $\begin{array}{c}-0.150 \\
(0.167)\end{array}$ \\
\hline Painted in 3 rd or 4 th years after death of sibling or friend & $\begin{array}{c}0.159 \\
(0.182)\end{array}$ & $\begin{array}{l}0.0856 \\
(0.191)\end{array}$ \\
\hline Observations & 12705 & 12705 \\
\hline Artist fixed effects & Yes & Yes \\
\hline Year of sale fixed effects & Yes & Yes \\
\hline $\begin{array}{l}\text { Cohort fixed effects interacted with } \\
\text { age, age }{ }^{2}, \text { age }^{3}, \text { age }^{4} \\
\text { Painting date fixed effects }\end{array}$ & $\begin{array}{l}\text { Yes } \\
\text { No }\end{array}$ & $\begin{array}{l}\text { Yes } \\
\text { Yes }\end{array}$ \\
\hline
\end{tabular}

Standard errors in parentheses

Standard errors are robust, clustered by artist

Regressions are weighted by the inverse of the sum of the mean squared error for each artist

${ }^{*} p<0.05,{ }^{* *} p<0.01,{ }^{* * *} p<0.001 \quad 19$ 


\section{Inclusion in the Met's Collection}

Art historians and others often criticize price as not being a good measure of a painting's creativity or worth. It may be that more beautiful, but not necessarily more creative or important paintings, command higher prices. Another important concern is that the most creative paintings may not be on the market but are instead placed in a museum's collection.

Information on all paintings by the original 33 French Impressionist artists that are in the New York Metrolipitan Museum of Art's collection was collected and appended to the painting data in the original dataset. Paintings by 30 of the 33 artists were included in the online collection. Paintings by Marcel Duchamp, Roger Bissiere, and Andre Masson did not appear in the online data (though there was work in other media by Duchamp in the collection). In total, 412 paintings were appended; the artist with the most paintings is Picasso with 37, and the artists with the least number of paintings, but still included in the collection, are Jean Arp and Henri Rousseau, each with 2 .

Figure 1 summarizes the data by looking at the proportion of the number of works in the Met's collection relative to the number of works sold at auction in each year, where the year is expressed relative to the year of death of the relative or friend. Figure 1 is striking. In the dataset with this selection of artists, only 2 works produced in the second year after the death of a friend or relative were included in the Met's collection, in comparison to 16 in the 
Figure 1: Inclusion in the Met's Collection

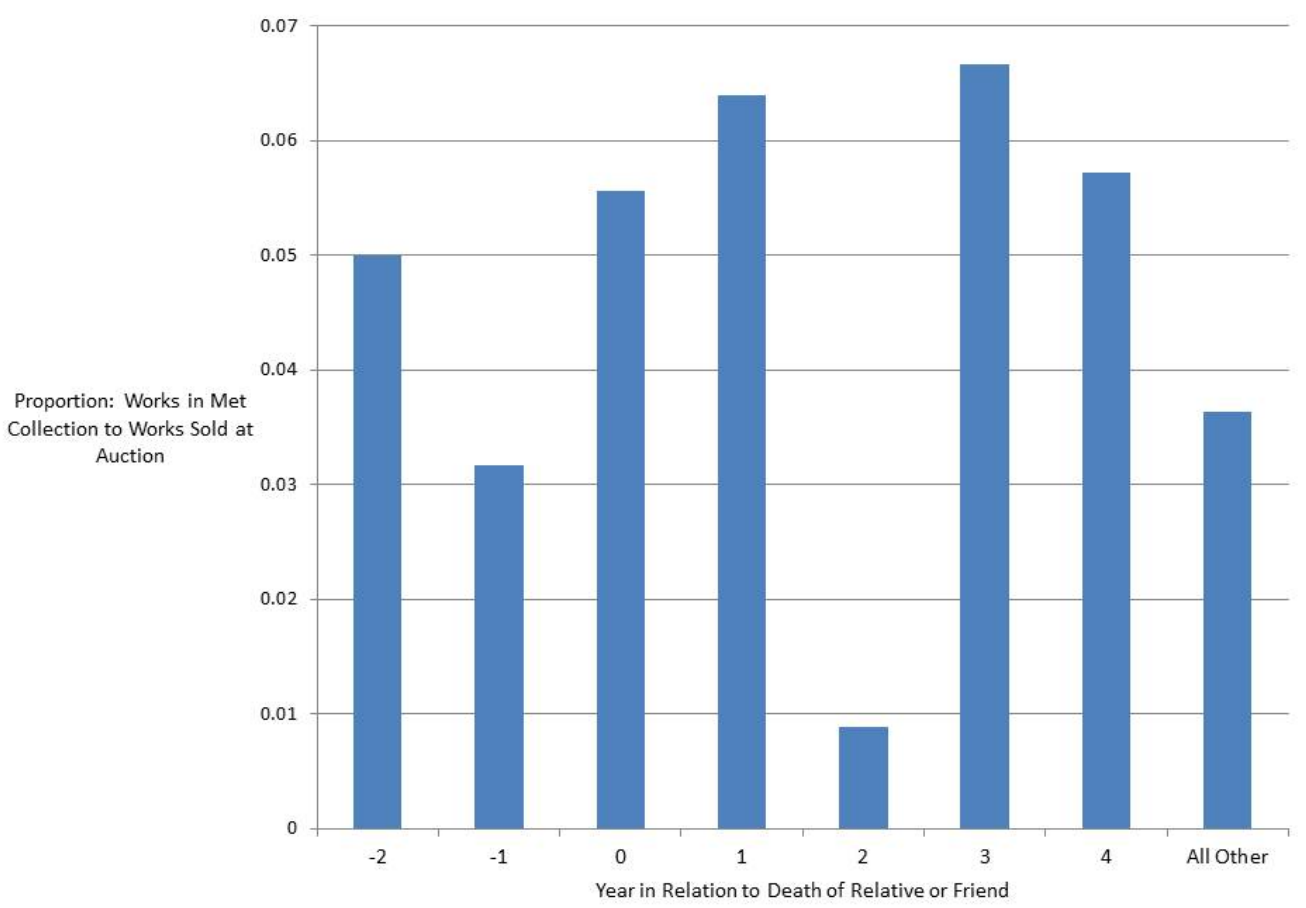

year prior ( 1 year after the death of the artist's friend or relative) and 17 in the year following (3 years after the death of the artist's friend or relative).

The results of a probit analysis, where a one-zero variable indicating whether a painting is included in the Met's collection, is regressed on the independent variables described in equation 1 above. The original dataset started with 14,044 observations from the auction dataset collected from the Blouin Art Sales Index (including those without price). 3,364 observations were subtracted which included all American artists, Marcel Duchamp, Roger Bissiere, and Andre Masson, and then 412 observations were added from the 
Met's collection, ending with 11,092 observations. Column 1 of Table VIII reports the results without painting date fixed effects, and column 2 reports the results with painting date fixed effects. The results are consistent with the pattern shown in Figure 1: works that were painted in the second year after after the death of the artist were significantly less likely to be included in the collection. However, while not statistically significant, the coefficient on works painted in the first year after death is not significantly different from the coefficient on works painted in the second year after death.

\section{Interpretation and Conclusion}

This research has used both prices of paintings, as determined by the auction mechanism years after the works have been executed, and inclusion in the Metropolitan Museum of Art's collection to infer the "creativity" of the artist at the time he worked on the painting. This use of prices relies on the assumption that, on average, prices are a valid measure of the artist's creativity at different points in his life. An exhibition of a painting in a museum is widely thought to be a signal of artistic merit.

The analysis has determined that artists, in the two years following the death of a friend or relative, are on average less creative than at other times of their lives. Paintings that were created in the year following a death fetch significantly less at auction than those created at other times in an artist's life. Paintings that were created two years after a death are significantly less 
Table IX: Included in the Metropolitan Museum of Art's Collection (Probit)

\begin{tabular}{lcc}
\hline \hline & $(1)$ & $(2)$ \\
\hline met & & \\
Painted 1 or 2 years prior to death & $-0.244^{*}$ & $-0.294^{*}$ \\
& $(0.102)$ & $(0.115)$ \\
& -0.135 & 0.222 \\
Painted in year of death & $(0.132)$ & $(0.128)$ \\
& -0.592 & -0.578 \\
Painted 1 year after death & $(0.327)$ & $(0.314)$ \\
& $-0.423^{* * *}$ & $-0.646^{* *}$ \\
Painted 2 years after death & $(0.0861)$ & $(0.237)$ \\
& 0.0402 & -0.0231 \\
Painted 3 or 4 years after death & $(0.126)$ & $(0.137)$ \\
& 11092 & 9443 \\
& Yes & Yes \\
Observations $_{\text {Artist fixed effects }}$ & & \\
Cohort fixed effects interacted with & Yes & Yes \\
age, age ${ }^{2}$, age ${ }^{3}$, age & \\
Painting date fixed effects & No & Yes \\
\hline \hline
\end{tabular}

Standard errors in parentheses

Standard errors are robust, clustered by artist.

Regressions are weighted by the inverse of the number of paintings for each artist 1,649 observations were dropped with painting date fixed effects because of colinearity ${ }^{*} p<0.05,{ }^{* *} p<0.01,{ }^{* * *} p<0.001$ 
likely to be included in the Met's collection. These findings coincide with the psychology literature on the effects of mood on creativity, and follow on Czikscentmihalyi's extensive work on "flow".

One potential problem with this research is that stories sometimes build around famous artists' lives, and these stories can affect which deaths are reported by biographers and other online sources. For example, all sources now cite Carlos Casagemas's death in relation to Picasso, because it is so well known. With other artists, it proved extremely difficult to find even the death dates of their parents. Only deaths that had a well-known and public impact on an artist's life may be the ones that are reported. It is difficult to know which way the potential bias may go from this sample selection, but it is certainly important to note that sample selection in death reporting could be a consideration.

Further research into the effects of death on creativity is called for. Azoulay's seminal paper on co-author death and the resulting effect on scientific creativity is very much in this realm, though the mechanism through which death affects creativity, the loss of scientific ideas, is very different in Azoulay's work than in this research. The results in this paper are consistent with a change in the creator's mood that results in work that was later deemed less valuable or important.

Researching biographies is very time consuming. It becomes more difficult with the number of year's ago that an artist lived (for example, there is less information on Old Masters than on the Impressionists) and with rel- 
atively contemporary artists. Nonetheless, this detailed data collection can yield surprising insights. More work in this area is called for.

While we have used art to document this creativity, primarily because it is relatively easy to determine when an artist paints a work and to find the work's subsequent market value, this research can extend to any area in which creativity plays a role. Notably, employers in creative industries should perhaps take note of this death effect and may wish to provide counseling. ${ }^{8}$ Not only could this be good for a worker's psychological health, but it could perhaps counteract reduced creativity related to bereavement.

\footnotetext{
${ }^{8}$ Some organizations already do provide counseling. A list of employee benefits posted in the mailroom at Brandeis cite "Bereavement Counseling" as one benefit.
} 
Orley Ashenfelter and Kathryn Graddy. Auctions and the price of art. Journal of Economic Literature, 41(3):763-787, 2003.

Pierre Azoulay, Joshua S. Graff Zivin, and Jialan Wang. Superstar extinction. The Quarterly Journal of Economics, 125(2):549-589, 2010.

Alan Beggs and Kathryn Graddy. Declining values and the afternoon effect: Evidence from art auctions. The Rand Journal of Economics, 28(3):544$565,1997$.

Karol Jan Borowiecki. How are you, my dearest mozart? well-being and creativity of three famous composers based on their letters. Discussion Papers on Business and Economics, University of Southern Denmark, 20, 2013.

Mihaly Csikszentmihalyi. Flow: The Psychology of Optimal Experience. Harper Collins, 1990.

Mihaly Csikszentmihalyi. Flow and the psychology of discovery and invention. HarperPerennial, New York, 39, 1997.

J. Marvin Eisenstadt. Parental loss and genius. American Psychologist, 33 (3):211 - 223, 1978.

David W Galenson and Bruce A Weinberg. Age and the quality of work: The case of modem american painters. The Journal of Political Economy, 108(4):761-777, 2000. 
David W Galenson and Bruce A Weinberg. Creating modern art: The changing careers of painters in france from impressionism to cubism. American Economic Review, 91(4):1063-1071, 2001.

Jacob W Getzels and Mihaly Csikszentmihalyi. The Creative Vision: A longitudinal Study of Problem Finding in Art. Wiley New York, 1976.

Victor Ginsburgh and Sheila Weyers. Creativity and life cycles of artists. Journal of Cultural Economics, 30(2):91-107, 2006.

Alice M Isen, Kimberly A Daubman, and Gary P Nowicki. Positive affect facilitates creative problem solving. Journal of personality and social psychology, 52(6):1122, 1987.

Rollo May. The nature of creativity. Creativity and its cultivation, pages 55-68, 1959.

Robert Keith Sawyer. The Science of Human Innovation: Explaining Creativity. New York: Oxford University Press, 2012.

Dean Keith Simonton. Genius, creativity, and leadership: Historiometric inquiries. Harvard University Press Cambridge, MA, 1984.

Dean Keith Simonton. Psychology, Science, and History: An Introduction to Historiometry. Yale University Press, 1990.

Karuna Subramaniam, John Kounios, Todd B Parrish, and Mark Jung- 
Beeman. A brain mechanism for facilitation of insight by positive affect. Journal of Cognitive Neuroscience, 21(3):415-432, 2009. 


\section{For Online Publication: Data Appendix}

A. References for American Artists

Anfam, David, Kline, Franz, Menil Collection (Houston Tex.), Whitney Museum of American Art, and Museum of Contemporary Art (Chicago Ill.), editors. Franz Kline : black $\mathscr{G}$ white, 1950-1961. Houston, Tex. : Menil Collection : Houston Fine Art Press, 1994.

Arnason H., Harvard. Robert Motherwell. New York: Abrams, 1982.

Gottlieb, Adolph. Adolph Gottlieb, a retrospective. New York : Published by the Arts Publisher, Inc. in association with the Adolph and Esther Gottlieb Foundation, Inc., 1981.

Guston, Philip. Philip Guston retrospective. Fort Worth : Modern Art Museum of Fort Worth : Thames \& Hudson, 2003.

Matossian, Nouritza. Black angel : a life of Arshile Gorky. London : Chatto \& Windus, 1998.

Neel, Alice, Temkin, Ann, Rosenberg, Susan, Flood Richard, and Whitney Museum of American Art, editors. Alice Neel. New York : Harry N. Abrams in association with Philadelphia Museum of Art, 2000.

Newman, Barnett. Barnett Newman. Philadelphia, Pa. : Philadelphia Museum of Art in association with Yale University Press, 2002. 
Porter, Fairfield. Fairfield Porter : realist painter in an age of abstraction. Boston, Mass. : Museum of Fine Arts, 1982.

Reinhardt, Ad. Ad Reinhardt. New York, N.Y. : Rizzoli International Publications, 1991.

Rothko, Mark. Mark Rothko, 1903-1970 : a retrospective. New York : H. N. Abrams, 1978.

Spike, John T. Fairfield Porter, an American classic. New York: Abrams, 1992.

Varnedoe, Kirk. Jackson Pollock. New York : The Museum of Modern Art Distributed in the U.S. and Canada by Harry N. Abrams London : Distributed outside the U.S. and Canada by Tate Gallery Pub., Ltd., 1998.

B. References for French Artists

Arp, Hans, later Jean. Benezit Dictionary of Artists, Oxford Art Online. Accessed February 20, 2015.

Bissière, Roger. Benezit Dictionary of Artists, Oxford Art Online. Accessed February 20, 2015.

Bonnard, Pierre. Benezit Dictionary of Artists, Oxford Art Online. Accessed February 20, 2015. 
Braque, Georges. Benezit Dictionary of Artists, Oxford Art Online. Accessed February 20, 2015.

Cézanne, Paul. Benezit Dictionary of Artists, Oxford Art Online. Accessed February 25, 2015.

Chagall, Marc. Benezit Dictionary of Artists, Oxford Art Online. Accessed February 25, 2015.

Degas, Hilaire Germain Edgar. Benezit Dictionary of Artists, Oxford Art Online. Accessed February 27, 2015.

Delaunay, Robert. Benezit Dictionary of Artists, Oxford Art Online. Accessed February 27, 2015.

Derain, André. Benezit Dictionary of Artists, Oxford Art Online. Accessed February 28, 2015.

Duchamp, Marcel. Benezit Dictionary of Artists, Oxford Art Online. Accessed February 28, 2015.

Dufy, Raoul. Benezit Dictionary of Artists, Oxford Art Online. Accessed March 1, 2015.

Gauguin, Paul. Benezit Dictionary of Artists, Oxford Art Online. Accessed March 1, 2015.

Gris, Juan. Benezit Dictionary of Artists, Oxford Art Online. Accessed March 2, 2015. 
Léger, Fernand. Benezit Dictionary of Artists, Oxford Art Online. Accessed March 2, 2015.

Manet, Édouard. Benezit Dictionary of Artists, Oxford Art Online. Accessed March 3, 2015.

MassoN, André. Benezit Dictionary of Artists, Oxford Art Online. Accessed March 3, 2015.

Matisse, Henri. Benezit Dictionary of Artists, Oxford Art Online. Accessed March 3, 2015.

Miró, Joan. Benezit Dictionary of Artists, Oxford Art Online. Accessed March 5, 2015.

Monet, Claude. Benezit Dictionary of Artists, Oxford Art Online. Accessed March 5, 2015.

Picabia, Francis. Benezit Dictionary of Artists, Oxford Art Online, a. Accessed March 12, 2015.

PICASSO, Pablo. Benezit Dictionary of Artists, Oxford Art Online, b. Accessed March 12, 2015.

Pissarro, Camille. Benezit Dictionary of Artists, Oxford Art Online. Accessed March 12, 2015.

Redon, Odilon. Benezit Dictionary of Artists, Oxford Art Online. Accessed March 12, 2015. 
Renoir, Pierre-Auguste. Benezit Dictionary of Artists, Oxford Art Online. Accessed March 12, 2015.

Rouault, Georges. Benezit Dictionary of Artists, Oxford Art Online, a. Accessed March 13, 2015.

Rousseau, Henri Julien Félix. Benezit Dictionary of Artists, Oxford Art Online, b. Accessed March 2, 2015.

Seurat, Georges Pierre. Benezit Dictionary of Artists, Oxford Art Online. Accessed March 13, 2015.

Soutine, Chaim. Benezit Dictionary of Artists, Oxford Art Online. Accessed March 13, 2015.

Tanguy, YVES. Benezit Dictionary of Artists, Oxford Art Online. Accessed March 13, 2015.

Toulouse-lautrec, Henri de. Benezit Dictionary of Artists, Oxford Art Online. Accessed February 27, 2015.

Gogh, Vincent Willem van. Benezit Dictionary of Artists, Oxford Art Online. Accessed March 13, 2015.

Vlaminck, Maurice de. Benezit Dictionary of Artists, Oxford Art Online. Accessed February 27, 2015.

Vuillard, Édouard. Benezit Dictionary of Artists, Oxford Art Online. Accessed March 13, 2015. 
Whitney Chadwick. Masson, André. Grove Art Online, Oxford Art Online. Accessed March 3, 2015.

Susan Compton. Chagall, Marc. Grove Art Online, Oxford Art Online. Accessed February 25, 2015.

José Corredor-Matheos. Miró, Joan. Grove Art Online, Oxford Art Online. Accessed March 5, 2015.

Anne Distel. Renoir, Auguste. Grove Art Online, Oxford Art Online. Accessed March 12, 2015.

Hajo Düchting, Tag Gronberg, and Nele Bernheim. Delaunay (ii). Grove Art Online, Oxford Art Online. Accessed February 27, 2015.

Beatrice Farwell. Manet, Edouard. Grove Art Online, Oxford Art Online. Accessed March 3, 2015.

Judi Freeman. Léger, Fernand. Grove Art Online, Oxford Art Online. Accessed March 2, 2015.

Julia Bloch Frey. Toulouse-Lautrec, Henri de. Grove Art Online, Oxford Art Online. Accessed February 27, 2015.

Colette Giraudon. Soutine, Chaïm. Grove Art Online, Oxford Art Online. Accessed March 13, 2015.

Christopher Green. Gris, Juan. Grove Art Online, Oxford Art Online. Accessed March 2, 2015. 
Marianne Heinz. Picabia, Francis. Grove Art Online, Oxford Art Online. Accessed March 12, 2015.

Richard Hobbs. Redon, Odilon. Grove Art Online, Oxford Art Online. Accessed March 12, 2015.

Joel Isaacson. Monet, Claude. Grove Art Online, Oxford Art Online. Accessed March 5, 2015.

Lewis Kachur. Braque, Georges. Grove Art Online, Oxford Art Online. Accessed February 20, 2015.

Jane Lee. Derain, André. Grove Art Online, Oxford Art Online. Accessed February 28, 2015.

Christopher Lloyd. Pissarro. Grove Art Online, Oxford Art Online. Accessed March 12, 2015.

Melissa McQuillan. Picasso, Pablo. Grove Art Online, Oxford Art Online. Accessed March 12, 2015.

Danielle Molinari. Rouault, Georges. Grove Art Online, Oxford Art Online. Accessed March 13, 2015.

Geneviève Monnier. Cézanne, Paul. Grove Art Online, Oxford Art Online, a. Accessed February 25, 2015.

Geneviève Monnier. Degas, Edgar. Grove Art Online, Oxford Art Online, b. Accessed February1 27, 2015. 
Francis M. Naumann. Duchamp, Marcel. Grove Art Online, Oxford Art Online. Accessed February 28, 2015.

Dora Pérez-Tibi. Dufy, Raoul. Grove Art Online, Oxford Art Online. Accessed March 1, 2015.

José Pierre. Tanguy, Yves. Grove Art Online, Oxford Art Online. Accessed March 13, 2015.

Rodolphe Rapetti. Gauguin, Paul. Grove Art Online, Oxford Art Online. Accessed March 1, 2015.

Jean Selz. Vlaminck, Maurice de. Grove Art Online, Oxford Art Online. Accessed February 27, 2015.

Paul Smith. Seurat, Georges. Grove Art Online, Oxford Art Online. Accessed March 13, 2015.

Greta Stroeh. Arp, Hans. Grove Art Online, Oxford Art Online. Accessed February 21, 2015.

Antoine Terrasse. Bonnard, Pierre. Grove Art Online, Oxford Art Online. Accessed February 20, 2015.

Belinda Thomson. Vuillard, Edouard. Grove Art Online, Oxford Art Online. Accessed March 13, 2015.

Evert van Uitert. Gogh, Vincent van. Grove Art Online, Oxford Art Online. Accessed March 13, 2015. 
Nicholas Watkins. Matisse, Henri. Grove Art Online, Oxford Art Online. Accessed March 3, 2015.

Sarah Wilson. Bissière, Roger. Grove Art Online, Oxford Art Online. Accessed February 20, 2015. 


\title{
Death, Bereavement, and Creativity
}

\author{
Kathryn Graddy ${ }^{2}$
}

July 23,2015

${ }^{1}$ Brandeis University, kgraddy@brandeis.edu,tel:7817368616

${ }^{2}$ Thanks to Carl Lieberman for excellent research assistance and for participants in the Faculty Lunch at Brandeis and the Art Markets Workshop in Brussels for comments. 


\begin{abstract}
Does creativity, on average, increase or decrease during bereavement? Dates of death of relatives and close friends of 33 French artists and 15 American artists were gathered from electronic sources and biographies, and information on over 15,000 paintings was collected from Blouin's Art Sales Index and the Metropolitan Museum of Art's online collection, including over 12,000 observations on price. To preview the results, an event study indicates that prices of paintings decrease by over one-third on average in the two years following the death of a friend or relative. Furthermore, paintings that were created during this bereavement period are less likely to be included in the the Met's collection.
\end{abstract}




\section{Introduction}

The death of a friend or relative is universally recognized as a painful experience. Whether the psychological pain resulting from the death increases or decreases creativity is not known. On the one hand, incidental observation of the history of art suggests that bereavement is correlated to the production of great art. For example, in 1901, Pablo Picasso's good friend, Carlos Casagemas, committed suicide. Many art historians believe that this event launched Picasso into his Blue Period of painting, in which Picasso painted somber monochromastic works. Picasso's Blue Period has in the past achieved record prices at auction. ${ }^{1}$ On the other hand, questions remain as to the impact of bereavement on an artist's state of mind. In the field of psychology, state of mind has long been associated with creativity through the idea of being completely absorbed in an activity, named by Michael Csikszentmihalyi as a "flow state" (May (1959), Getzels and Csikszentmihalyi (1976), and Isen et al. (1987)). Bereavement can interupt flow and alter mood. The empirical question of whether the death of a relative or close friend on average increases or decreases creativity in the years immediately following the death is addressed by this research.

Dates of death for friends and relatives of the French artists used in this study were gathered from Oxford Art Online, reading both Grove Art Online

\footnotetext{
${ }^{1}$ In 2000, Woman with Crossed Arms broke a previous record for Picasso paintings by selling for 38 million pounds. This price pales, however, next to the recent sale of the Women of Algiers (Version O) for $\$ 179$ million at Christie's during May of 2015.
} 
and the Benezit Dictionary of Artists. For the American artists used in this study, dates of death were gathered primarily from biographies. Information on over 15,000 paintings was gathered from Blouin's Art Sales Index and the Metropolitan Museum of Art's online collection, including over 12,000 observations on price. The basic economic premises of this research are that price reflects a painting's importance within an artist's oeuvre, and that an artist's most important paintings are likely to be included in Met's collection.

While art is a convenient medium in which to study the effect of a close friend's or relative's death on creativity, the results should extend to other creative endeavors, such as scientific creativity. The attraction of studying art in order to measure the effect of bereavement is that it is known when a painting is produced, and the importance of a creation can be measured by its price and inclusion in a museum's collection. The data exist in art that enable researchers to measure this psychological effect, whereas in other areas, the effect would be more difficult to measure.

This paper proceeds as follows. In section II, the psychology literature on creativity is briefly reviewed. In section III the paper details the data collection procedures and regression methodology. In section IV, the price regression results are presented, and robustness of the price regressions is discussed in section V. Section VI analyses inclusion in the Metropolitan Museum of Art's collection, and section VII concludes the analysis. 


\section{Creativity and State of Mind}

The concept of a "flow state" that people enter when being very creative has gained acceptance by psychologists. As described by Keith Sawyer (Sawyer (2012), p. 78), Rollo May was one of the first researchers to describe the experience of being in a creative state as experiencing intensity of awareness, heightened consciousness, and obvliousness to the environment and to the passage of time (May (1959)). Czikscentmihalyi continued this strand of research, and coined the term "flow state" (Getzels and Csikszentmihalyi (1976)). During flow, people are at their most creative. Csikszentmihalyi did further studies that showed that in all professions people feel at their peak when they are most creative, and therefore through flow individuals can achieve happiness (Csikszentmihalyi (1990)).

Distraction is an enemy of flow and creativity. At best, it could take hours to regain the peace of mind to resume a creative endeavour. At worst, "More serious health, family, or financial problems could occupy the mind of a person so insistently that he or she is no longer able to devote enough attention to work. Then a long period of drought may follow, a writer's block, a burnout, which may even end a creative career" (Csikszentmihalyi (1997), p.120). Through interupting flow, death and bereavement can reduce creativity.

Psychologists then surmised that if the flow experience is correlated with enhanced creativity, then mood is related to creativity. Using experiements, 
researchers showed that mood is strongly related to problem solving (Isen et al. (1987)), (Subramaniam et al. (2009)). Death and bereavement interupt flow and can result in sadness and depression.

To date, there have been few if any empirical studies that have related mood to creativity, though economists and others have used empirical methods to document productivity over the life cycle. Galenson and Weinberg (2000) and Galenson and Weinberg (2001) have extensively studied the productivity of artists over the lifecycle, and Simonton (1990) presents a general study of other professions. The idea for this study came from a case study of three musicians by Karol Jan Borowiecki (2013) as presented at the Genius for Sale! conference in Oxford on May 8th, 2014.

Academic studies have related death to creativity through different venues. It is well documented that individuals deemed "geniuses" were more likely to have suffered a parental loss as a child or adolescent. See for example Eisenstadt (1978) and Simonton (1984). Indeed, of the 15 American artists included in this study, four artists (Mark Rothko, Arshile Gorky, Franz Kline, and Philip Guston) all experienced the death of a parent as a child. In a very interesting and original study, Azoulay et al. (2010) looked at unexpected deaths of "superstar" researchers and subsequent productivity of coauthors. They find a lasting decline of between $5 \%$ and $8 \%$ in quality adjusted publication output of the coauthors. They explain this lasting decline by the loss of an irreplaceable source of ideas.

The research in this paper is very different in spirit. All individuals 
experience loss through death of a close relative or friend at some point in their lives, geniuses and superstars included. This paper seeks to measure the effect of this loss on creative output. The hypothesis is that alteration in mood and inability to focus during bereavement may affect creative output.

\section{Data and Methodology}

The question of the effect of death on creativity is addressed with prices on over 10,000 paintings produced by 33 French impressionist artists and over 2,000 paintings by 15 modern American artists born between 1900 and 1920. The auction data were gathered online from Blouin's Art Sales Index. ${ }^{2}$ The sale dates range from 1972 to 2014. In addition, information on 412 paintings in the Metropolitan Museum of Art's collection was downloaded from the Met's website. ${ }^{3}$

The artists chosen were those first analyzed in Galenson and Weinberg (2000) and Galenson and Weinberg (2001). The French impressionists were originally chosen by Galenson and Weinberg according to importance to art history and connection to France. Galenson and Weinberg wanted to choose two different cohorts of American artists, with the first cohort, which is used in this paper, dominated by abstract expressionists. ${ }^{4}$ The French artists used

\footnotetext{
${ }^{2}$ The url for Blouin's Art Sales Index is http://artsalesindex.artinfo.com/asi/search.action and the data were downloaded during June of 2014.

${ }^{3}$ The url for the Met's collection is http://www.metmuseum.org/collection/thecollection-online and the website was accessed on June 15, 2015.

${ }^{4}$ I had originally planned to gather death data on both cohorts of American artists. But, given the difficulty, relative to the French cohort, of gathering data on the first
} 
in this study are listed in Table I, and the American artists used in this study are listed in Table II, along with the number of deaths of friends and relatives that were found for each artist. All French impressionists and American abstract expressionists that were studied by Galenson and Weinberg (2001) and Galenson and Weinberg (2000) are included in this table, even those artists on whom we were unable to find death data for their friends or relatives. The death dates for the French artists were gathered from Oxford Art Online, reading both Grove Art Online and the Benezit Dictionary of Artists, and the death dates of American artists were gathered from websites and biographies. Appendix A includes the references used for American artists, and Appendix B includes the references used for French artists.

When gathering the data, Oxford Art Online was not useful for any of the American artists, and it was necessary to use a mixture of websites and biographies from the library to collect the data. Probably because of genealogy records, deaths of parents were much more assiduously recorded for the American artists, who lived more recently, than the French artists. A mythology has also likely grown around the lives of both sets of artists, perhaps more so around the French impressionists, that may affect the reporting of certain deaths.

Summary statistics for this dataset, broken up by French artists and American artists, are presented in Table III. The prices presented are in American cohort, and since most of the second cohort of artists are still alive, I stopped after the first American cohort. 
Table I: French Artists

\begin{tabular}{lc}
\hline \hline French Artists & Deaths \\
\hline Jean Arp (b. 1886, d. 1966) & 1 \\
Roger Bissiere (b. 1884, d. 1964) & 4 \\
Pierre Bonnard (b. 1867, d. 1947) & 2 \\
Georges Braque (b. 1882, d. 1963) & 1 \\
Paul Cezanne (b. 1839, d. 1906) & 3 \\
Marc Chagall (b. 1887, d. 1985) & 2 \\
Maurice de Vlaminck (b. 1876, d. 1958) & 0 \\
Henri de Toulouse-Lautrec (b. 1864, d. 1901) & 0 \\
Edgar Degas (b. 1834, d. 1917) & 2 \\
Robert Delaunay (b. 1885, d. 1941) & 0 \\
Andre Derain (b. 1880, d. 1954) & 0 \\
Marcel Duchamp (b. 1887, d. 1968) & 0 \\
Raoul Dufy (b. 1877, d. 1953) & 0 \\
Paul Gauguin (b. 1848, d. 1903) & 3 \\
Juan Gris (b. 1887, d. 1927) & 0 \\
Henri Julien Felix Rousseau (b. 1844, d. 1910) & 3 \\
Fernand Leger (b. 1881, d. 1955) & 2 \\
Edouard Manet (b. 1832, d. 1883) & 2 \\
Andre Masson (b. 1896, d. 1987) & 1 \\
Henri Matisse (b. 1869, d. 1954) & 1 \\
Joan Miro (b. 1893, d. 1983) & 2 \\
Claude Monet (b. 1840, d. 1926) & 5 \\
Francis Picabia (b. 1879, d. 1953) & 0 \\
Pablo Picasso (b. 1881, d. 1973) & 1 \\
Camille Pissarro (b. 1830, d. 1903) & 5 \\
Odilon Redon (b. 1840, d. 1916) & 0 \\
Pierre-Auguste Renoir (b. 1841, d. 1919) & 1 \\
Georges Rouault (b. 1871, d. 1958) & 2 \\
Georges Seurat (b. 1859, d. 1891) & 0 \\
Chaim Soutine (b. 1893, d. 1943) & 1 \\
Yves Tanguy (b. 1900, d. 1955) & \\
Vincent van Gogh (b. 1853, d. 1890) & \\
Edouard Vuillard (b. 1868, d. 1940) & \\
\hline \hline &
\end{tabular}


Table II: American Artists

\begin{tabular}{lc}
\hline \hline American Artists & Deaths \\
\hline Willem de Kooning (b. 1904, d. 1997) & 2 \\
Arshile Gorky (b. 1904, d. 1948) & 3 \\
Adolph Gottlieb (b. 1903, d. 1974) & 3 \\
Philip Guston (b. 1913, d. 1980) & 3 \\
Franz Kline (b. 1910, d. 1962) & 1 \\
Morris Louis (b. 1912, d. 1962) & 0 \\
Agnes Martin (b. 1912, d. 2004) & 1 \\
Robert Motherwell (b. 1915, d. 1991) & 2 \\
Alice Neel (b. 1900, d. 1984) & 3 \\
Barnett Newman (b. 1905, d. 1970) & 4 \\
Jackson Pollock (b. 1912, d. 1956) & 3 \\
Fairfield Porter (b. 1907, d. 1975) & 2 \\
Ad Reinhardt (b. 1913, d. 1967) & 0 \\
Mark Rothko (b. 1903, d. 1970) & 1 \\
Clyfford Still (b. 1904, d. 1980) & 2 \\
\hline \hline
\end{tabular}

2010 dollars and are deflated by the CPI. The French artists were born earlier on average than the American artists. The price and age variables are similar to one another, but there are over twice as many paintings per French impressionist as there are paintings for each American artist included in the dataset.

An event study is used for the regression analysis. For the event study, each sale is an observation. As shown in equation 1 below, the dependent variable is the natural log of the price of painting $i$ that was sold at time j. A zero-one variable is created that indicates whether the painting was produced the first or second year prior to the death of the friend or relative, Prior $_{i j}$. Unless the death was foreseeable, this variable should not have an 
Table III: Summary Statistics

\begin{tabular}{lccc}
\hline \hline & French & American & All \\
\hline Year of birth & 1872 & 1908 & 1878 \\
& $(19)$ & $(5)$ & $(22)$ \\
Painting date & 1924 & 1962 & 1931 \\
& $(28)$ & $(12)$ & $(30)$ \\
Age of artist & 53 & 54 & 53 \\
& $(18)$ & $(12)$ & $(17)$ \\
Year of sale & 2002 & 2001 & 2002 \\
& $(9)$ & $(10)$ & $(9)$ \\
Price & 1463567 & 1517807 & 1472652 \\
& $(4376458)$ & $(5586213)$ & $(4601108)$ \\
\hline Observations & 11752 & 2292 & 14044 \\
Number of artists & 33 & 15 & 48 \\
Paintings per artist & 545 & 223 & 492 \\
\hline \hline Note:Standard deviations are in parentheses. Prices in 2010 dollars are deflated with the CPI. \\
Source: Blouin Art Sales Index; see text.
\end{tabular}


effect. Another zero-one variable indicating whether the friend or relative died during the year the work was painted, Current $_{i j}$, is also created. It is not possible to establish when in a year the painting was created or whether the death occurred before or after a particular work was created. Two more variables are created, $A f t e r(1)_{i j}$ and $A f t e r(2)_{i j}$, indicating whether the work was produced in the 1st or 2nd year following the death of a friend or relative. Finally, a variable, After $(3,4)_{i j}$, was created indicating whether the work was painted in the 3rd or 4th year after the death of the friend or relative. The coefficients on these variables are $\alpha_{1}$ through $\alpha_{5}$, as indicated in equation 1 below.

Five different cohorts, interacted with $a g e, a g e^{2}, a g e^{3}$, and $a g e^{4}$, are used for controls. Cohorts one through four coincide with the four cohorts for French painters used by Galenson and Weinburg (2001). That is, cohort 1 consists of French painters in the dataset born between 1820 and 1839, cohort 2 consists of those French painters born between 1840 and 1859, cohort 3 consists of those French painters born between 1860 and 1879, and cohort 4 consists of those French painters born between 1880 and 1900 . Cohort 5 consists of American painters and coincides with Galenson and Weinberg's (2000) first cohort of American painters. The cohorts have coefficients $\beta_{1}$ through $\beta_{5}$. Artist fixed effects with coefficients $\psi_{k}$, year fixed effects with coefficients $\theta_{y}$, and in the full specification, fixed effects for painting date, with coefficients $\omega_{y}$, and an error term, $\epsilon_{i j}$ are also included in the regressions. These controls are similar to those used in Galenson and Weinberg (2000) 
and Galenson and Weinberg (2001). ${ }^{5}$

$$
\begin{aligned}
& \ln \left(\text { Price }_{i j}=\alpha_{1} \text { Prior }_{i}+\alpha_{2} \text { Current }_{i}+\alpha_{3} \text { After }(1)_{i}+\alpha_{4} \text { After }(2)_{i}+\alpha_{5} \text { After }(3,4)_{i}\right. \\
& +\sum_{c=1}^{4}\left[\beta_{1}^{c} A_{g e_{i}}+\beta_{2}^{c} A g e_{i}^{2}+\beta_{3}^{c} A g e_{i}^{3}+\beta_{4}^{c} A g e_{i}^{4}\right] I\left(\text { cohort }_{i}=C\right) \\
& +\sum_{k=1}^{48} \psi_{k} I(i=k)+\sum_{y=1972}^{2014} \theta_{y} I\left(\text { Saleyear }_{j}=y\right) \\
& +\sum_{y=1840}^{y=1972} \omega_{y} I\left(\text { Paintingdate }_{i}\right)+\epsilon_{i j}
\end{aligned}
$$

\section{Results}

Of the 14,044 observations, a sale price was observed for 12,705 observations. The auction results included 164 paintings by American artists and 1,175 paintings by French artists that went unsold at auction because they did not meet the reserve price. ${ }^{6}$ The results from estimating regression equation 1 are presented in Table IV.

Columns 1 and 3 present the results of unweighted regressions, and columns 2 and 4 present weighted regressions. Columns 3 and 4 include painting date fixed effects and columns 1 and 2 do not. To control for differ-

\footnotetext{
${ }^{5}$ Area of work was used in these papers, but was not originally collected for this dataset. Section V.A. describes a specification that was used to test for robustness with respect to area.

${ }^{6}$ Note that the Blouin Art Sales Index does not include all unsold items from all auctions.
} 
ences in the variability of different artists' sale prices, each artist's paintings are weighted by the mean square error for that artist. Unweighted regressions implicitly weight artists with more sales more heavily than artists with fewer sales. As the mean squared error takes into account both the number of works for sale and the variability in sale prices, the inverse of the mean squared error appears to be the correct weight. The results are similar when each work is weighted by the inverse of the number of paintings by an artist, so that each artist receives equal weight. Robust errors are calculated with the observations clustered by artist.

Results are consistent in both the weighted and unweighted regressions. The weighted regressions indicate that the value of a painting decreases by about $50 \%$ for paintings created in the year following the death of the artists' friend or relative. There is no significant effect in other years. These results are consistent with the psychology literature relating to mood and creativity, but not consistent with the popular idea that suffering necessarily increases artistic creativity.

In order to check that the results are consistent with the results of Galenson and Weinberg (2001), the peak age of earnings for each French Impressionist are estimated using regression equation 1, weighted by the inverse of the mean squared error and including painting date fixed effects. These estimated peak ages are presented in Table V. The results are similar, with peak age of artist declining by year cohort. ${ }^{7}$ This research supports

\footnotetext{
${ }^{7}$ Galenson and Weinberg explain this decline by the hypothesis that artists in the
} 
Table IV: Determinants of Sale Price

\begin{tabular}{|c|c|c|c|c|}
\hline & (1) & $(2)$ & 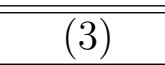 & (4) \\
\hline Painted in 1st or 2 nd year prior to death & $\begin{array}{l}-0.0299 \\
(0.143)\end{array}$ & $\begin{array}{c}0.223 \\
(0.160)\end{array}$ & $\begin{array}{c}0.130 \\
(0.151)\end{array}$ & $\begin{array}{l}0.0980 \\
(0.148)\end{array}$ \\
\hline Painted in year of death & $\begin{array}{l}-0.127 \\
(0.119)\end{array}$ & $\begin{array}{c}-0.333 \\
(0.271)\end{array}$ & $\begin{array}{l}-0.180 \\
(0.240)\end{array}$ & $\begin{array}{l}-0.111 \\
(0.173)\end{array}$ \\
\hline Painted in 1st year after death & $\begin{array}{c}-0.409^{* * *} \\
(0.0944)\end{array}$ & $\begin{array}{c}-0.415^{*} \\
(0.199)\end{array}$ & $\begin{array}{c}-0.470^{* *} \\
(0.161)\end{array}$ & $\begin{array}{c}-0.530^{* * *} \\
(0.131)\end{array}$ \\
\hline Painted in 2 nd year after death & $\begin{array}{c}-0.247^{*} \\
(0.116)\end{array}$ & $\begin{array}{c}-0.0414 \\
(0.198)\end{array}$ & $\begin{array}{l}-0.228 \\
(0.173)\end{array}$ & $\begin{array}{l}-0.245 \\
(0.160)\end{array}$ \\
\hline Painted in 3rd or 4th year after death & $\begin{array}{l}0.0109 \\
(0.149)\end{array}$ & $\begin{array}{c}0.387 \\
(0.228)\end{array}$ & $\begin{array}{c}0.169 \\
(0.163)\end{array}$ & $\begin{array}{c}0.134 \\
(0.191)\end{array}$ \\
\hline Observations & 12705 & 12705 & 12705 & 12705 \\
\hline Artist fixed effects & Yes & Yes & Yes & Yes \\
\hline Year of sale fixed effects & Yes & Yes & Yes & Yes \\
\hline $\begin{array}{l}\text { Cohort fixed effects interacted with } \\
\text { age, age }^{2}, \text { age }^{3}, \text { age }^{4} \\
\text { Painting date fixed effects }\end{array}$ & $\begin{array}{l}\text { Yes } \\
\text { No }\end{array}$ & $\begin{array}{l}\text { Yes } \\
\text { No }\end{array}$ & $\begin{array}{l}\text { Yes } \\
\text { No }\end{array}$ & $\begin{array}{l}\text { Yes } \\
\text { Yes }\end{array}$ \\
\hline
\end{tabular}

Standard errors in parentheses

Standard errors are robust, clustered by artist

Regressions in columns (1) and (3) are unweighted

Regressions in columns (2) and (4) are weighted

by the inverse of the sum of the mean squared error for each artist

${ }^{*} p<0.05,{ }^{* *} p<0.01,{ }^{* * *} p<0.001$ 
their empirical analysis with a different dataset of sales. These sales took place from 1972 through 2014; the Galenson and Weinberg sales took place from 1980 to 1996.

\begin{tabular}{|c|c|c|c|c|}
\hline & \multicolumn{4}{|c|}{ French Artists } \\
\hline & $1820-1839$ & $1840-1859$ & 1860-1879 & $1880-1900$ \\
\hline Peak Age Estimates & 53 & 49 & 30 & 27 \\
\hline $\begin{array}{l}\text { Galenson and Weinberg } \\
\text { Peak Age Estimates* }\end{array}$ & 48 & 38 & 28 & 28 \\
\hline
\end{tabular}

Notes:*Galenson and Weinberg (2001)

\section{Robustness Checks}

This section checks for robustness in three ways. First, this section checks whether including size of painting changes the results. Secondly, this section checks whether the results differ in the dataset on French Impressionists from the results in the dataset on American Modern painters. Finally, this section checks if the results depend upon whether a parent has died or whether a sibling or friend has died.

latest cohort were "conceptualists," valuing new ideas above technique, and artists in the earlier cohort were "experimentalists," whose style developed slowly through trialand-error experimentation. Conceptualists reach their peak production age earlier than experiementalists. Ginsburgh and Weyers (2006) provide a critique of this hypothesis. 


\section{V.A. Size of Work}

The dataset on prices and deaths put together for this research did not contain information on the size of a work. As the variable of interest is death, this omission could impact the results if size of work is correlated with mood. In order to check for this possibility, the average area (height times width) of work for each French Impressionist artist at each age of the artist was collected from the dataset used in Ashenfelter and Graddy (2003) and Beggs and Graddy (1997). If an age was missing for a particular artist, the size was replaced with the average size painted at the previous age for that artist. If information on size was missing for the artist overall (the Modern American painters were not included in these datasets), the artist was dropped. Results are presented in Table VI.

Once the sample is taken into account, the inclusion of area has almost no effect: none of the coefficients in the regression models including area are statistically significantly different from any of the coefficients in the regression models not including area. However, in this change of sample, the coefficients on year of death, 1st year after death and 2nd year after death all become statistically significantly negative, strengthening the previous results.

\section{V.B. French Impressionists Compared to Modern Americans}

The increased significance of death on price in the year of death and 1st and 2nd year following death in the above regression sample raises the question as to whether death effects in the sample of French Impressionist painters differ 
Table VI: Determinants of Sale Price: Sample with Area

\begin{tabular}{lcccc}
\hline \hline & $\begin{array}{c}(1) \\
\text { lnprice }\end{array}$ & $\begin{array}{c}(2) \\
\text { lnprice }\end{array}$ & $\begin{array}{c}(3) \\
\text { lnprice }\end{array}$ & $\begin{array}{c}(4) \\
\text { lnprice }\end{array}$ \\
\hline ln Area & $0.168^{*}$ & $0.161^{* *}$ & & \\
& $(0.0723)$ & $(0.0525)$ & & \\
Painted in 1st or 2nd year prior to death & -0.134 & -0.174 & -0.167 & -0.191 \\
& $(0.134)$ & $(0.172)$ & $(0.135)$ & $(0.173)$ \\
& $-0.715^{*}$ & $-0.692^{* *}$ & $-0.732^{*}$ & $-0.705^{* *}$ \\
Painted in year of death & $(0.294)$ & $(0.189)$ & $(0.289)$ & $(0.188)$ \\
& $-0.535^{*}$ & $-0.520^{* *}$ & $-0.611^{*}$ & $-0.587^{* *}$ \\
& $(0.252)$ & $(0.163)$ & $(0.247)$ & $(0.163)$ \\
Painted in 1st year after death & $-0.456^{* *}$ & $-0.529^{* * *}$ & $-0.496^{* *}$ & $-0.560^{* * *}$ \\
& $(0.158)$ & $(0.137)$ & $(0.148)$ & $(0.130)$ \\
& & & & \\
Painted in 2nd year after death & 0.110 & 0.0188 & 0.109 & 0.0122 \\
& $(0.241)$ & $(0.220)$ & $(0.237)$ & $(0.216)$ \\
\hline Painted in 3rd or 4th year after death & 8035 & 8035 & 8035 & 8035 \\
& Yes & Yes & Yes & Yes \\
& Yes & Yes & Yes & Yes \\
Observations $_{\text {Artist fixed effects }}$ & & & & \\
Year of sale fixed effects & Yes & Yes & Yes & Yes \\
Cohort fixed effects interacted with & No & Yes & No & Yes \\
age, age ${ }^{2}$, age ${ }^{3}$, age & & & & \\
Painting date fixed effects & & & &
\end{tabular}

Standard errors in parentheses

Standard errors are robust, clustered by artist.

Regressions are weighted by the inverse of the mean squared error for each artist

${ }^{*} p<0.05,{ }^{* *} p<0.01,{ }^{* * *} p<0.001$ 
from death effects in the sample of Modern American painters. In Table VII, a set of new variables is created by interacting an indicator variable, equal to 1 if the artist is a French Impressionist and 0 if not, with painting dates relative to deaths.

The coefficients on the Modern American painters are not precisely estimated, which is not surprising given the smaller sample of only 15 Modern American painters. However, the point estimates for works created in the year after death are consistent with other results. Furthermore, the estimates of the coefficient on works painted one year after death are statistically significantly lower than the coefficients on works painted 1 or 2 years prior to the death of the artist. The coefficients on the French Impressionist artists are statistically significantly negative for works created in the 1st and 2nd year after death of a friend or relative.

\section{V.C. Parent Death Compared to a Sibling or Friend Death}

In Table 8 , yet another set of new variables is created by interacting an indicator variable, equal to 1 if a parent has died, and 0 if a sibling or friend has died, with painting dates relative to these deaths.

The results indicate there is no statistically significant difference whether the death involved a parent, or whether the death involved a sibling or friend. 
Table VII: Determinants of Sale Price

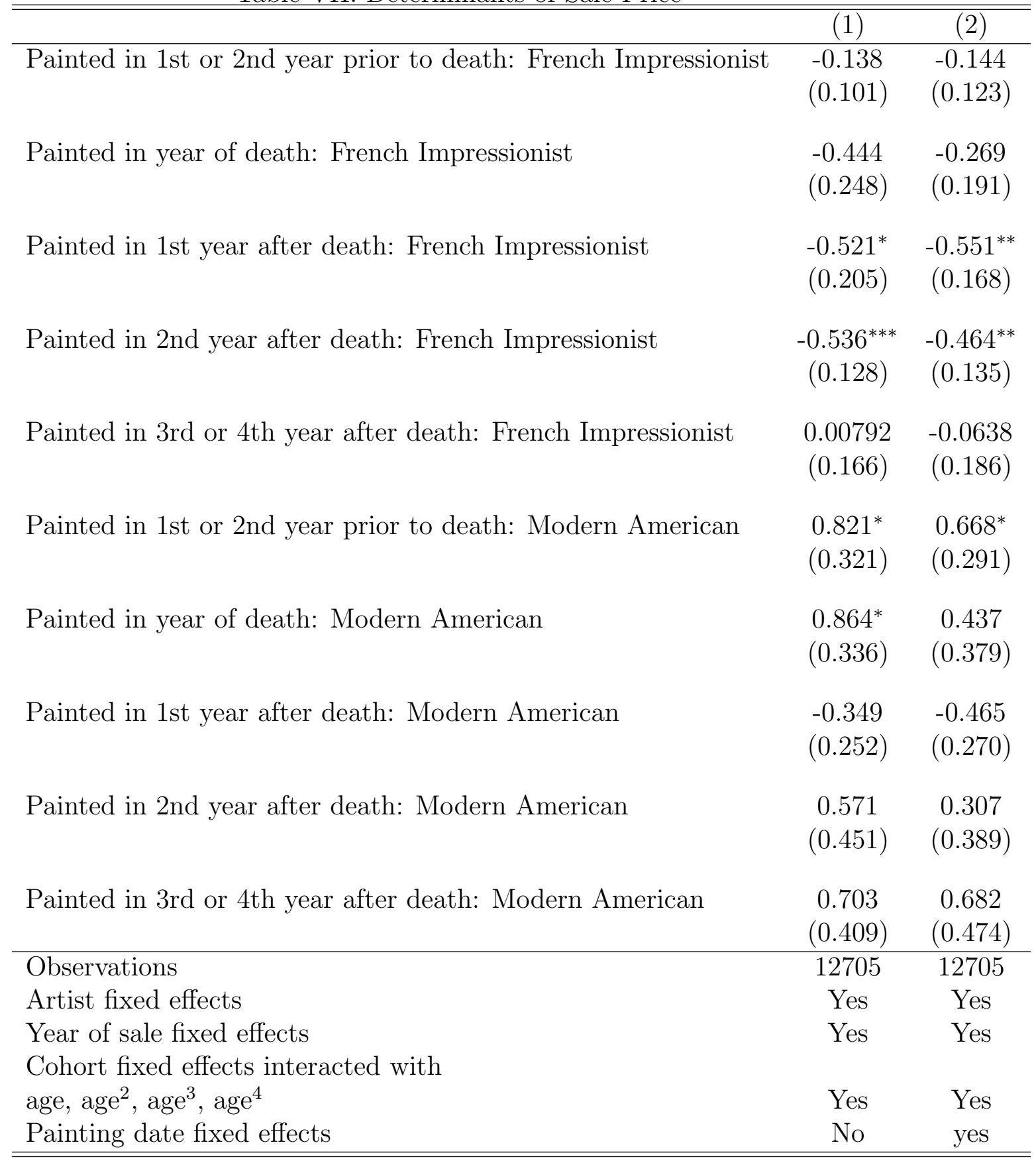

Standard errors in parentheses

Standard errors are robust, clustered by artist.

Regressions are weighted by the inverse of the mean squared error for each artist

${ }^{*} p<0.05,{ }^{* *} p<0.01,{ }^{* * *} p<0.001 \quad 18$ 
Table VIII: Determinants of Sale Price

\begin{tabular}{|c|c|c|}
\hline & (1) & $(2)$ \\
\hline Painted in 1st or 2nd year prior to death of parent & $\begin{array}{c}0.339 \\
(0.320)\end{array}$ & $\begin{array}{c}0.160 \\
(0.317)\end{array}$ \\
\hline Painted in year of death of parent & $\begin{array}{l}-0.220 \\
(0.609)\end{array}$ & $\begin{array}{c}-0.0902 \\
(0.312)\end{array}$ \\
\hline Painted in 1st year after death of parent & $\begin{array}{c}-0.679 \\
(0.381)\end{array}$ & $\begin{array}{c}-0.752^{*} \\
(0.288)\end{array}$ \\
\hline Painted in 2nd year after death of parent & $\begin{array}{l}-0.317 \\
(0.408)\end{array}$ & $\begin{array}{c}-0.554 \\
(0.397)\end{array}$ \\
\hline Painted in 3rd or 4th year after death of parent & $\begin{array}{c}0.171 \\
(0.336)\end{array}$ & $\begin{array}{c}0.107 \\
(0.332)\end{array}$ \\
\hline Painted in 1st or 2nd year prior to death of sibling or friend & $\begin{array}{c}0.0308 \\
(0.121)\end{array}$ & $\begin{array}{l}0.0635 \\
(0.127)\end{array}$ \\
\hline Painted in year of death of sibling or friend & $\begin{array}{c}-0.169 \\
(0.213)\end{array}$ & $\begin{array}{c}-0.0890 \\
(0.230)\end{array}$ \\
\hline Painted in 1st year after death of sibling or friend & $\begin{array}{c}-0.374^{*} \\
(0.164)\end{array}$ & $\begin{array}{c}-0.411^{*} \\
(0.175)\end{array}$ \\
\hline Painted in 2nd year after death of sibling or friend & $\begin{array}{c}-0.202 \\
(0.188)\end{array}$ & $\begin{array}{c}-0.150 \\
(0.167)\end{array}$ \\
\hline Painted in 3 rd or 4 th years after death of sibling or friend & $\begin{array}{c}0.159 \\
(0.182)\end{array}$ & $\begin{array}{l}0.0856 \\
(0.191)\end{array}$ \\
\hline Observations & 12705 & 12705 \\
\hline Artist fixed effects & Yes & Yes \\
\hline Year of sale fixed effects & Yes & Yes \\
\hline $\begin{array}{l}\text { Cohort fixed effects interacted with } \\
\text { age, age }{ }^{2}, \text { age }^{3}, \text { age }^{4} \\
\text { Painting date fixed effects }\end{array}$ & $\begin{array}{l}\text { Yes } \\
\text { No }\end{array}$ & $\begin{array}{l}\text { Yes } \\
\text { Yes }\end{array}$ \\
\hline
\end{tabular}

Standard errors in parentheses

Standard errors are robust, clustered by artist

Regressions are weighted by the inverse of the sum of the mean squared error for each artist

${ }^{*} p<0.05,{ }^{* *} p<0.01,{ }^{* * *} p<0.001 \quad 19$ 


\section{Inclusion in the Met's Collection}

Art historians and others often criticize price as not being a good measure of a painting's creativity or worth. It may be that more beautiful, but not necessarily more creative or important paintings, command higher prices. Another important concern is that the most creative paintings may not be on the market but are instead placed in a museum's collection.

Information on all paintings by the original 33 French Impressionist artists that are in the New York Metrolipitan Museum of Art's collection was collected and appended to the painting data in the original dataset. Paintings by 30 of the 33 artists were included in the online collection. Paintings by Marcel Duchamp, Roger Bissiere, and Andre Masson did not appear in the online data (though there was work in other media by Duchamp in the collection). In total, 412 paintings were appended; the artist with the most paintings is Picasso with 37, and the artists with the least number of paintings, but still included in the collection, are Jean Arp and Henri Rousseau, each with 2 .

Figure 1 summarizes the data by looking at the proportion of the number of works in the Met's collection relative to the number of works sold at auction in each year, where the year is expressed relative to the year of death of the relative or friend. Figure 1 is striking. In the dataset with this selection of artists, only 2 works produced in the second year after the death of a friend or relative were included in the Met's collection, in comparison to 16 in the 
Figure 1: Inclusion in the Met's Collection

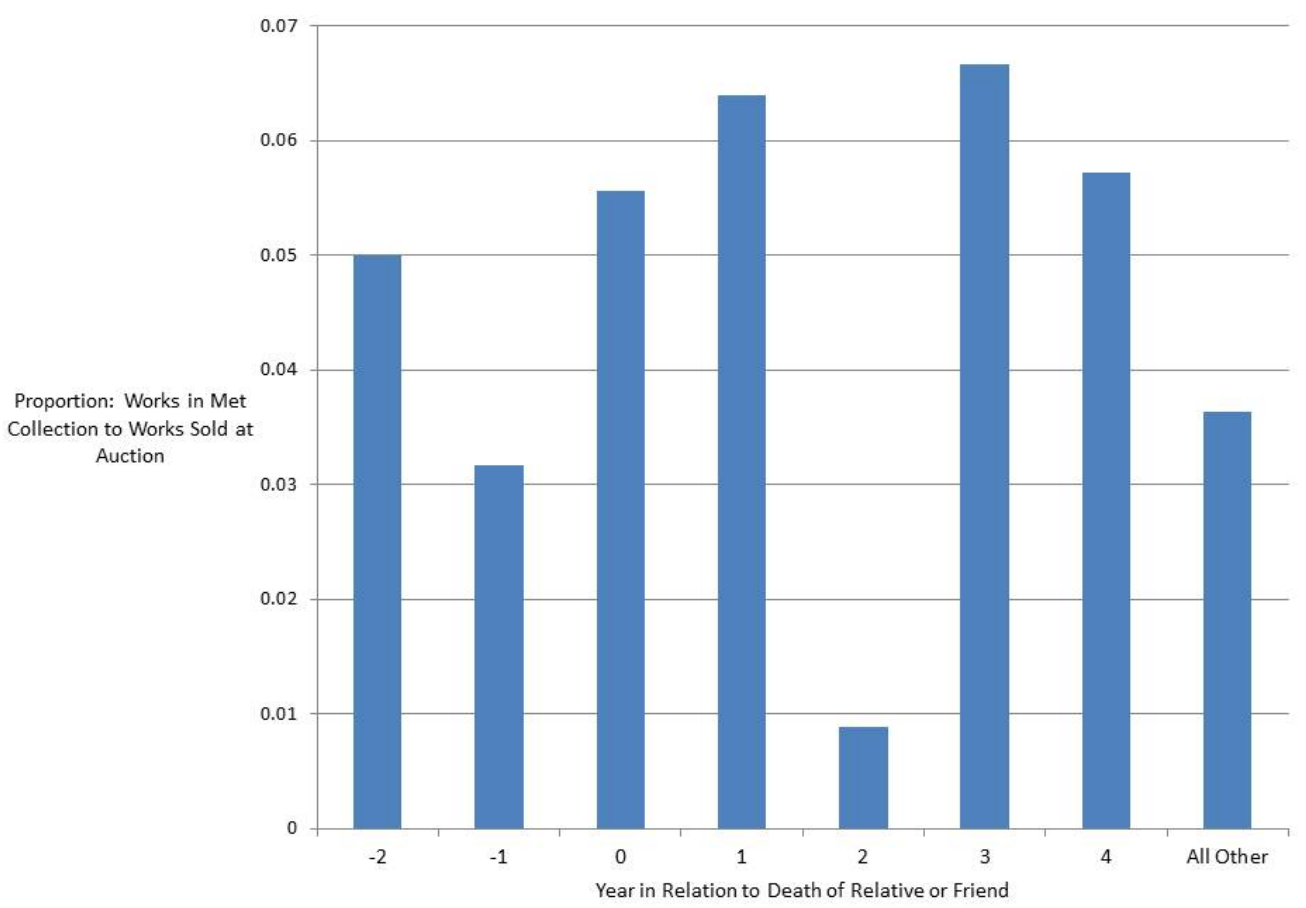

year prior ( 1 year after the death of the artist's friend or relative) and 17 in the year following (3 years after the death of the artist's friend or relative).

The results of a probit analysis, where a one-zero variable indicating whether a painting is included in the Met's collection, is regressed on the independent variables described in equation 1 above. The original dataset started with 14,044 observations from the auction dataset collected from the Blouin Art Sales Index (including those without price). 3,364 observations were subtracted which included all American artists, Marcel Duchamp, Roger Bissiere, and Andre Masson, and then 412 observations were added from the 
Met's collection, ending with 11,092 observations. Column 1 of Table VIII reports the results without painting date fixed effects, and column 2 reports the results with painting date fixed effects. The results are consistent with the pattern shown in Figure 1: works that were painted in the second year after after the death of the artist were significantly less likely to be included in the collection. However, while not statistically significant, the coefficient on works painted in the first year after death is not significantly different from the coefficient on works painted in the second year after death.

\section{Interpretation and Conclusion}

This research has used both prices of paintings, as determined by the auction mechanism years after the works have been executed, and inclusion in the Metropolitan Museum of Art's collection to infer the "creativity" of the artist at the time he worked on the painting. This use of prices relies on the assumption that, on average, prices are a valid measure of the artist's creativity at different points in his life. An exhibition of a painting in a museum is widely thought to be a signal of artistic merit.

The analysis has determined that artists, in the two years following the death of a friend or relative, are on average less creative than at other times of their lives. Paintings that were created in the year following a death fetch significantly less at auction than those created at other times in an artist's life. Paintings that were created two years after a death are significantly less 
Table IX: Included in the Metropolitan Museum of Art's Collection (Probit)

\begin{tabular}{lcc}
\hline \hline & $(1)$ & $(2)$ \\
\hline met & & \\
Painted 1 or 2 years prior to death & $-0.244^{*}$ & $-0.294^{*}$ \\
& $(0.102)$ & $(0.115)$ \\
& -0.135 & 0.222 \\
Painted in year of death & $(0.132)$ & $(0.128)$ \\
& -0.592 & -0.578 \\
Painted 1 year after death & $(0.327)$ & $(0.314)$ \\
& $-0.423^{* * *}$ & $-0.646^{* *}$ \\
Painted 2 years after death & $(0.0861)$ & $(0.237)$ \\
& 0.0402 & -0.0231 \\
Painted 3 or 4 years after death & $(0.126)$ & $(0.137)$ \\
& 11092 & 9443 \\
& Yes & Yes \\
Observations $_{\text {Artist fixed effects }}$ & & \\
Cohort fixed effects interacted with & Yes & Yes \\
age, age ${ }^{2}$, age ${ }^{3}$, age & \\
Painting date fixed effects & No & Yes \\
\hline \hline
\end{tabular}

Standard errors in parentheses

Standard errors are robust, clustered by artist.

Regressions are weighted by the inverse of the number of paintings for each artist 1,649 observations were dropped with painting date fixed effects because of colinearity ${ }^{*} p<0.05,{ }^{* *} p<0.01,{ }^{* * *} p<0.001$ 
likely to be included in the Met's collection. These findings coincide with the psychology literature on the effects of mood on creativity, and follow on Czikscentmihalyi's extensive work on "flow".

One potential problem with this research is that stories sometimes build around famous artists' lives, and these stories can affect which deaths are reported by biographers and other online sources. For example, all sources now cite Carlos Casagemas's death in relation to Picasso, because it is so well known. With other artists, it proved extremely difficult to find even the death dates of their parents. Only deaths that had a well-known and public impact on an artist's life may be the ones that are reported. It is difficult to know which way the potential bias may go from this sample selection, but it is certainly important to note that sample selection in death reporting could be a consideration.

Further research into the effects of death on creativity is called for. Azoulay's seminal paper on co-author death and the resulting effect on scientific creativity is very much in this realm, though the mechanism through which death affects creativity, the loss of scientific ideas, is very different in Azoulay's work than in this research. The results in this paper are consistent with a change in the creator's mood that results in work that was later deemed less valuable or important.

Researching biographies is very time consuming. It becomes more difficult with the number of year's ago that an artist lived (for example, there is less information on Old Masters than on the Impressionists) and with rel- 
atively contemporary artists. Nonetheless, this detailed data collection can yield surprising insights. More work in this area is called for.

While we have used art to document this creativity, primarily because it is relatively easy to determine when an artist paints a work and to find the work's subsequent market value, this research can extend to any area in which creativity plays a role. Notably, employers in creative industries should perhaps take note of this death effect and may wish to provide counseling. ${ }^{8}$ Not only could this be good for a worker's psychological health, but it could perhaps counteract reduced creativity related to bereavement.

\footnotetext{
${ }^{8}$ Some organizations already do provide counseling. A list of employee benefits posted in the mailroom at Brandeis cite "Bereavement Counseling" as one benefit.
} 
Orley Ashenfelter and Kathryn Graddy. Auctions and the price of art. Journal of Economic Literature, 41(3):763-787, 2003.

Pierre Azoulay, Joshua S. Graff Zivin, and Jialan Wang. Superstar extinction. The Quarterly Journal of Economics, 125(2):549-589, 2010.

Alan Beggs and Kathryn Graddy. Declining values and the afternoon effect: Evidence from art auctions. The Rand Journal of Economics, 28(3):544$565,1997$.

Karol Jan Borowiecki. How are you, my dearest mozart? well-being and creativity of three famous composers based on their letters. Discussion Papers on Business and Economics, University of Southern Denmark, 20, 2013.

Mihaly Csikszentmihalyi. Flow: The Psychology of Optimal Experience. Harper Collins, 1990.

Mihaly Csikszentmihalyi. Flow and the psychology of discovery and invention. HarperPerennial, New York, 39, 1997.

J. Marvin Eisenstadt. Parental loss and genius. American Psychologist, 33 (3):211 - 223, 1978.

David W Galenson and Bruce A Weinberg. Age and the quality of work: The case of modem american painters. The Journal of Political Economy, 108(4):761-777, 2000. 
David W Galenson and Bruce A Weinberg. Creating modern art: The changing careers of painters in france from impressionism to cubism. American Economic Review, 91(4):1063-1071, 2001.

Jacob W Getzels and Mihaly Csikszentmihalyi. The Creative Vision: A longitudinal Study of Problem Finding in Art. Wiley New York, 1976.

Victor Ginsburgh and Sheila Weyers. Creativity and life cycles of artists. Journal of Cultural Economics, 30(2):91-107, 2006.

Alice M Isen, Kimberly A Daubman, and Gary P Nowicki. Positive affect facilitates creative problem solving. Journal of personality and social psychology, 52(6):1122, 1987.

Rollo May. The nature of creativity. Creativity and its cultivation, pages 55-68, 1959.

Robert Keith Sawyer. The Science of Human Innovation: Explaining Creativity. New York: Oxford University Press, 2012.

Dean Keith Simonton. Genius, creativity, and leadership: Historiometric inquiries. Harvard University Press Cambridge, MA, 1984.

Dean Keith Simonton. Psychology, Science, and History: An Introduction to Historiometry. Yale University Press, 1990.

Karuna Subramaniam, John Kounios, Todd B Parrish, and Mark Jung- 
Beeman. A brain mechanism for facilitation of insight by positive affect. Journal of Cognitive Neuroscience, 21(3):415-432, 2009. 


\section{For Online Publication: Data Appendix}

A. References for American Artists

Anfam, David, Kline, Franz, Menil Collection (Houston Tex.), Whitney Museum of American Art, and Museum of Contemporary Art (Chicago Ill.), editors. Franz Kline : black $\mathscr{G}$ white, 1950-1961. Houston, Tex. : Menil Collection : Houston Fine Art Press, 1994.

Arnason H., Harvard. Robert Motherwell. New York: Abrams, 1982.

Gottlieb, Adolph. Adolph Gottlieb, a retrospective. New York : Published by the Arts Publisher, Inc. in association with the Adolph and Esther Gottlieb Foundation, Inc., 1981.

Guston, Philip. Philip Guston retrospective. Fort Worth : Modern Art Museum of Fort Worth : Thames \& Hudson, 2003.

Matossian, Nouritza. Black angel : a life of Arshile Gorky. London : Chatto \& Windus, 1998.

Neel, Alice, Temkin, Ann, Rosenberg, Susan, Flood Richard, and Whitney Museum of American Art, editors. Alice Neel. New York : Harry N. Abrams in association with Philadelphia Museum of Art, 2000.

Newman, Barnett. Barnett Newman. Philadelphia, Pa. : Philadelphia Museum of Art in association with Yale University Press, 2002. 
Porter, Fairfield. Fairfield Porter : realist painter in an age of abstraction. Boston, Mass. : Museum of Fine Arts, 1982.

Reinhardt, Ad. Ad Reinhardt. New York, N.Y. : Rizzoli International Publications, 1991.

Rothko, Mark. Mark Rothko, 1903-1970 : a retrospective. New York : H. N. Abrams, 1978.

Spike, John T. Fairfield Porter, an American classic. New York: Abrams, 1992.

Varnedoe, Kirk. Jackson Pollock. New York : The Museum of Modern Art Distributed in the U.S. and Canada by Harry N. Abrams London : Distributed outside the U.S. and Canada by Tate Gallery Pub., Ltd., 1998.

B. References for French Artists

Arp, Hans, later Jean. Benezit Dictionary of Artists, Oxford Art Online. Accessed February 20, 2015.

Bissière, Roger. Benezit Dictionary of Artists, Oxford Art Online. Accessed February 20, 2015.

Bonnard, Pierre. Benezit Dictionary of Artists, Oxford Art Online. Accessed February 20, 2015. 
Braque, Georges. Benezit Dictionary of Artists, Oxford Art Online. Accessed February 20, 2015.

Cézanne, Paul. Benezit Dictionary of Artists, Oxford Art Online. Accessed February 25, 2015.

Chagall, Marc. Benezit Dictionary of Artists, Oxford Art Online. Accessed February 25, 2015.

Degas, Hilaire Germain Edgar. Benezit Dictionary of Artists, Oxford Art Online. Accessed February 27, 2015.

Delaunay, Robert. Benezit Dictionary of Artists, Oxford Art Online. Accessed February 27, 2015.

Derain, André. Benezit Dictionary of Artists, Oxford Art Online. Accessed February 28, 2015.

Duchamp, Marcel. Benezit Dictionary of Artists, Oxford Art Online. Accessed February 28, 2015.

Dufy, Raoul. Benezit Dictionary of Artists, Oxford Art Online. Accessed March 1, 2015.

Gauguin, Paul. Benezit Dictionary of Artists, Oxford Art Online. Accessed March 1, 2015.

Gris, Juan. Benezit Dictionary of Artists, Oxford Art Online. Accessed March 2, 2015. 
Léger, Fernand. Benezit Dictionary of Artists, Oxford Art Online. Accessed March 2, 2015.

Manet, Édouard. Benezit Dictionary of Artists, Oxford Art Online. Accessed March 3, 2015.

MassoN, André. Benezit Dictionary of Artists, Oxford Art Online. Accessed March 3, 2015.

Matisse, Henri. Benezit Dictionary of Artists, Oxford Art Online. Accessed March 3, 2015.

Miró, Joan. Benezit Dictionary of Artists, Oxford Art Online. Accessed March 5, 2015.

Monet, Claude. Benezit Dictionary of Artists, Oxford Art Online. Accessed March 5, 2015.

Picabia, Francis. Benezit Dictionary of Artists, Oxford Art Online, a. Accessed March 12, 2015.

PICASSO, Pablo. Benezit Dictionary of Artists, Oxford Art Online, b. Accessed March 12, 2015.

Pissarro, Camille. Benezit Dictionary of Artists, Oxford Art Online. Accessed March 12, 2015.

Redon, Odilon. Benezit Dictionary of Artists, Oxford Art Online. Accessed March 12, 2015. 
Renoir, Pierre-Auguste. Benezit Dictionary of Artists, Oxford Art Online. Accessed March 12, 2015.

Rouault, Georges. Benezit Dictionary of Artists, Oxford Art Online, a. Accessed March 13, 2015.

Rousseau, Henri Julien Félix. Benezit Dictionary of Artists, Oxford Art Online, b. Accessed March 2, 2015.

Seurat, Georges Pierre. Benezit Dictionary of Artists, Oxford Art Online. Accessed March 13, 2015.

Soutine, Chaim. Benezit Dictionary of Artists, Oxford Art Online. Accessed March 13, 2015.

Tanguy, YVES. Benezit Dictionary of Artists, Oxford Art Online. Accessed March 13, 2015.

Toulouse-lautrec, Henri de. Benezit Dictionary of Artists, Oxford Art Online. Accessed February 27, 2015.

Gogh, Vincent Willem van. Benezit Dictionary of Artists, Oxford Art Online. Accessed March 13, 2015.

Vlaminck, Maurice de. Benezit Dictionary of Artists, Oxford Art Online. Accessed February 27, 2015.

Vuillard, Édouard. Benezit Dictionary of Artists, Oxford Art Online. Accessed March 13, 2015. 
Whitney Chadwick. Masson, André. Grove Art Online, Oxford Art Online. Accessed March 3, 2015.

Susan Compton. Chagall, Marc. Grove Art Online, Oxford Art Online. Accessed February 25, 2015.

José Corredor-Matheos. Miró, Joan. Grove Art Online, Oxford Art Online. Accessed March 5, 2015.

Anne Distel. Renoir, Auguste. Grove Art Online, Oxford Art Online. Accessed March 12, 2015.

Hajo Düchting, Tag Gronberg, and Nele Bernheim. Delaunay (ii). Grove Art Online, Oxford Art Online. Accessed February 27, 2015.

Beatrice Farwell. Manet, Edouard. Grove Art Online, Oxford Art Online. Accessed March 3, 2015.

Judi Freeman. Léger, Fernand. Grove Art Online, Oxford Art Online. Accessed March 2, 2015.

Julia Bloch Frey. Toulouse-Lautrec, Henri de. Grove Art Online, Oxford Art Online. Accessed February 27, 2015.

Colette Giraudon. Soutine, Chaïm. Grove Art Online, Oxford Art Online. Accessed March 13, 2015.

Christopher Green. Gris, Juan. Grove Art Online, Oxford Art Online. Accessed March 2, 2015. 
Marianne Heinz. Picabia, Francis. Grove Art Online, Oxford Art Online. Accessed March 12, 2015.

Richard Hobbs. Redon, Odilon. Grove Art Online, Oxford Art Online. Accessed March 12, 2015.

Joel Isaacson. Monet, Claude. Grove Art Online, Oxford Art Online. Accessed March 5, 2015.

Lewis Kachur. Braque, Georges. Grove Art Online, Oxford Art Online. Accessed February 20, 2015.

Jane Lee. Derain, André. Grove Art Online, Oxford Art Online. Accessed February 28, 2015.

Christopher Lloyd. Pissarro. Grove Art Online, Oxford Art Online. Accessed March 12, 2015.

Melissa McQuillan. Picasso, Pablo. Grove Art Online, Oxford Art Online. Accessed March 12, 2015.

Danielle Molinari. Rouault, Georges. Grove Art Online, Oxford Art Online. Accessed March 13, 2015.

Geneviève Monnier. Cézanne, Paul. Grove Art Online, Oxford Art Online, a. Accessed February 25, 2015.

Geneviève Monnier. Degas, Edgar. Grove Art Online, Oxford Art Online, b. Accessed February1 27, 2015. 
Francis M. Naumann. Duchamp, Marcel. Grove Art Online, Oxford Art Online. Accessed February 28, 2015.

Dora Pérez-Tibi. Dufy, Raoul. Grove Art Online, Oxford Art Online. Accessed March 1, 2015.

José Pierre. Tanguy, Yves. Grove Art Online, Oxford Art Online. Accessed March 13, 2015.

Rodolphe Rapetti. Gauguin, Paul. Grove Art Online, Oxford Art Online. Accessed March 1, 2015.

Jean Selz. Vlaminck, Maurice de. Grove Art Online, Oxford Art Online. Accessed February 27, 2015.

Paul Smith. Seurat, Georges. Grove Art Online, Oxford Art Online. Accessed March 13, 2015.

Greta Stroeh. Arp, Hans. Grove Art Online, Oxford Art Online. Accessed February 21, 2015.

Antoine Terrasse. Bonnard, Pierre. Grove Art Online, Oxford Art Online. Accessed February 20, 2015.

Belinda Thomson. Vuillard, Edouard. Grove Art Online, Oxford Art Online. Accessed March 13, 2015.

Evert van Uitert. Gogh, Vincent van. Grove Art Online, Oxford Art Online. Accessed March 13, 2015. 
Nicholas Watkins. Matisse, Henri. Grove Art Online, Oxford Art Online. Accessed March 3, 2015.

Sarah Wilson. Bissière, Roger. Grove Art Online, Oxford Art Online. Accessed February 20, 2015. 